\title{
Regulatory T Cells As Potential Targets for HIV Cure Research
}

\author{
Adam J. Kleinman ${ }^{1,2 \dagger}$, Ranjit Sivanandham ${ }^{1,3 \dagger}$, Ivona Pandrea ${ }^{1,3,4}$, Claire A. Chougnet ${ }^{5 *}$ \\ and Cristian Apetrei ${ }^{1,2,4 *}$
}

${ }^{1}$ Center for Vaccine Research, University of Pittsburgh, Pittsburgh, PA, United States, ${ }^{2}$ Department of Microbiology and
Molecular Genetics, School of Medicine, University of Pittsburgh, Pittsburgh, PA, United States, ${ }^{3}$ Department of Pathology,
School of Medicine, University of Pittsburgh, Pittsburgh, PA, United States, ${ }^{4}$ Department of Infectious Diseases and
Microbiology, Graduate School of Public Health, University of Pittsburgh, Pittsburgh, PA, United States, ${ }^{5}$ Division of
Immunobiology, Department of Pediatrics, Cincinnati Children's Hospital, Cincinnati University, Cincinnati, OH, United States

T regulatory cells (Tregs) are a key component of the immune system, which maintain a delicate balance between overactive responses and immunosuppression. As such,

\section{OPEN ACCESS}

Edited by:

Vijayakumar Velu,

Emory University, United States

Reviewed by:

Mirko Paiardini,

Emory University School of

Medicine, United States

Monica Vaccari,

National Institutes of Health

$(\mathrm{NIH})$, United States

*Correspondence:

Claire A. Chougnet

claire.chougnet@cchmc.org;

Cristian Apetrei

apetreic@pitt.edu

tThese authors have contributed equally to this work.

Specialty section: This article was submitted to Viral Immunology,

a section of the journal

Frontiers in Immunology

Received: 18 January 2018 Accepted: 23 March 2018

Published: 13 April 2018

Citation:

Kleinman AJ, Sivanandham R, Pandrea I, Chougnet CA and Apetrei C (2018) Regulatory

$T$ Cells As Potential Targets for HIV Cure Research.

Front. Immunol. 9:734.

doi: 10.3389/fimmu.2018.00734
Treg deficiencies are linked to autoimmune disorders and alter the immune control of pathogens. In HIV infection, Tregs play major roles, both beneficial and detrimental. They regulate the immune system such that inflammation and spread of virus through activated T cells is suppressed. However, suppression of immune activation also limits viral clearance and promotes reservoir formation. Tregs can be directly targeted by HIV, thereby harboring a fraction of the viral reservoir. The vital role of Tregs in the pathogenesis and control of HIV makes them a subject of interest for manipulation in the search of an HIV cure. Here, we discuss the origin and generation, homeostasis, and functions of Tregs, particularly their roles and effects in HIV infection. We also present various Treg manipulation strategies, including Treg depletion techniques and interventions that alter Treg function, which may be used in different cure strategies, to simultaneously boost HIV-specific immune responses and induce reactivation of the latent virus.

Keywords: regulatory T cells, FoxP3, human immunodeficiency virus, simian immunodeficiency virus, lymph node, virus eradication, cytotoxic T lymphocytes

\section{INTRODUCTION}

The human immune system walks a fine line between protection from pathogens and self-reactivity. These functions are mediated by both the innate and adaptive immune responses, such that all immune cells, from monocytes and natural killer cells to B and $\mathrm{T}$ lymphocytes, play integral roles in protection. Yet, a major function of the immune system, regulation, and self-tolerance, was not well understood for a long time. Gershon and Kondo in 1970 first described a population of thymus-derived lymphocytes, which were responsible for the induction of tolerance in bone marrow-derived lymphocytes (1). However, the mechanism of action and the cellular characteristics of these cells were not studied in detail until 1995, when Sakaguchi et al. reported that the $\mathrm{CD} 25^{\text {hi }} \mathrm{CD} 44^{+} \mathrm{T}$ cell subset has an immunoregulatory function and helps defend against the development of autoimmunity, rekindling the interest in this regulatory population (2). These cells have since been termed $\mathrm{T}$ regulatory cells (Tregs), and their immunosuppressive functions have been extensively investigated over the past 23 years. We now understand that Tregs are essential 
for proper homeostasis of the immune system and regulation of self-tolerance. While clearly playing a significant role in the pathogenesis of HIV infection, there is still debate in the field of whether Tregs are a boon or bane to fighting the virus. More recently, Tregs were reported to be involved in the HIV reservoir seeding, maintenance, and control of reactivation. In this review, we discuss Tregs and their roles during HIV infection, with emphasis on their role in viral persistence, and strategies for Treg manipulation that may have an impact for an HIV cure.

\section{TYPES OF Tregs}

Based on their site of differentiation, Tregs can be classified into thymic Tregs (tTregs) and peripheral Tregs (pTregs). The differences in the differentiation of tTregs and pTregs have been described in detail by Lee et al (3).

Separation based on their immunophenotypes identified numerous distinct Treg subpopulations (4) (Table 1). Treg classification through other methods, such as mass cytometry, also showed that they form a very diverse population, with up to 22 different Treg subsets being identified (5). In this section, we only focus on the key Treg subsets for which both immunophenotypes and function were well characterized.

Forkhead box P3 (FoxP3) is the key marker and master regulator of Tregs (6). In fact, Tregs are defined to have a $\mathrm{CD} 25^{\text {hi }}$ FoxP $^{+} \mathrm{CD}^{+}$phenotype. The importance of this protein was discovered when mutations in the foxp 3 gene that codes for FoxP3 were shown to cause the X-linked recessive disease, scurfy, in mice. Scurfy presents as lymphoproliferation leading to fatal autoimmunity, and mimics $\mathrm{X}$-linked autoimmunity-allergic dysregulation syndrome in humans (7). Scurfy mice administered with stable Tregs, defined by FoxP3 expression and full suppressive functionality, did not develop any signs of the disease (8). FoxP3 expression can also be transiently induced following in vitro stimulation of nonsuppressive $\mathrm{CD} 25^{\text {neg }} \mathrm{CD} 4^{+} \mathrm{T}$ cells, which indicates that expression of FoxP3 alone is not responsible for the regulatory activity of T cells (52).

Thymic Tregs are defined by the expression of CD25 and FoxP3 on $\mathrm{CD}^{+} \mathrm{T}$ cells. It has been shown that $\mathrm{CD} 25^{\text {hi }} \mathrm{CD} 4^{+}$ Treg cells develop from self-reactive thymic cells that express a $\mathrm{T}$ cell receptor (TCR) with high affinity for self-antigens. Differentiation occurs as an alternative mechanism to apoptosis, such that self-antigen reactivity can induce an inhibitory response instead of an autoimmune response (53). Upon TCR interaction with these peptide-major histocompatibility complex (MHC) complexes, FoxP3 is induced in the immature thymocytes (54). However, FoxP3 expression is not sufficient to create a stable Treg. Demethylation of the FoxP3 locus in the Treg-specific demethylated region (TSDR) is required to generate stable tTregs (55). In addition, CpG hypomethylation of certain loci called "Treg cell representative regions" is imprinted in Tregs, also contributing to their stability (56). Interactions between B7 molecules (CD80 and CD86), expressed on the antigen-presenting cells (APCs), and CD28, on thymocytes, are co-stimulatory and are critical to the thymic development of Tregs, as evidenced by the severe decrease in Treg numbers in mice either deficient in CD28 or treated with a blocking anti-B7 antibody $(15,57,58)$. Interleukin-2 (IL-2), the central cytokine involved in Treg biology, is also essential for tTreg maturation (59).

TABLE 1 | Key immunophenotypic markers/molecules and cytokines expressed by T regulatory cells (Tregs) and their function.

Function in Tregs

Reference

Marker/molecule

CD25

FoxP3 (forkhead box P3)

CD127 (Low)

CTLA-4 (Cytotoxic T lymphocyte antigen-4)/CD152

CD28

PD1 (Programmed cell death-1)

ICOS (Inducible costimulator)/CD278

LAG-3 (Lymphocyte activation gene-3)/CD223

GITR (Glucocorticoid-induced tumor necrosis factor receptor)/CD357

GARP (Glycoprotein A repetitions predominant)

TNFR2 (tumor necrosis factor receptor 2)/CD120b

Helios

CD39

$\mathrm{CD} 73$

CCR4

CCR6

CCR7

CXCR5

\section{Cytokines}

IL-10

TGF- $\beta$

IL-35
Receptor for IL-2, essential for Treg function and maintenance Co-ordinates expression of various genes required for Treg activity Receptor for IL-7

Ablates CD28 costimulation by competitive binding to CD80 and CD86. Upregulation of IDO production by DCs

Development and maturation, activation induced Treg markers and expression of CCR6

Binds to PD-L1, inhibits proliferation and effector responses of lymphocytes

Controls expansion and maintenance of the Foxp3+ regulatory T cells, and IL-10 production

Plays an important role during IL-27-mediated enhanced Treg function

Differentiation of thymic Tregs (tTregs), and expansion of both tTregs and pTregs

Present on activated Tregs; promote activation and secretion of TGF- $\beta$

Promotes sustained expression of FoxP3

Highly expressed on tTregs; enhances Treg function by increasing expression

of other Treg functional molecules

Anti-inflammatory effect by hydrolytically cleaving ATP to AMP

Anti-inflammatory effect by hydrolyzing AMP cleaved by CD39 to adenosine

Expressed on effector Tregs; required for recruitment to tissue, through CCL22

Regulates migration to inflammatory tissue

Required for migration to lymph nodes; limits Treg circulation back to the thymus

Expressed on Tfr cells; required for homing to the germinal centers

Secreted; anti-inflammatory

Membrane bound and secreted; suppressive; important for Treg trafficking to the gut

Secreted; suppressive
(2)

$(6-8)$

$(9,10)$

$(11-14)$

$(15,16)$

(17-19)

(20-22)

(23)

$(24,25)$

$(26,27)$

(28)

(29-32)

(33, 34)

$(32,35)$

(36-38)

(39)

(40-42)

(43) 
In addition to tTregs, it has become clear that de novo expression of FoxP 3 can occur in non-Treg $\mathrm{CD}^{+} \mathrm{T}$ cells, either in vitro or in vivo. Such induction of FoxP3 expression notably happens when naïve $\mathrm{T}$ cells are stimulated in the presence of transforming growth factor beta-1 (TGF- $\beta 1$ ) (60), leading to the development of a subset of induced Tregs (iTregs). This subset has extensively been used to study the functions and characteristics of Tregs ex vivo (61); however, it is now recognized that these in vitroinduced iTregs may not accurately portray the characteristics of in vivo-induced, pTregs. Notably, full FoxP3 TSDR methylation does not occur in TGF- $\beta$-induced Tregs, leading to poorly suppressive and unstable Tregs (62). Conflicting reports have been published with regard to the contribution of retinoic acid (RA) to pTreg differentiation. RA from dendritic cells (DCs) was reported to be a key cofactor in generating pTregs in the gut $(63,64)$. However, supplementation by RA does not increase Treg frequency (65), which has cast doubt on the role really played by RA in pTreg differentiation. Interestingly, RA can phosphorylate AKT (protein kinase B) (66), thereby reducing its activity, and this pathway could be involved in pTreg differentiation, because a constitutively active AKT has been shown to impair de novo induction of FoxP3 ${ }^{+}$cells (67). Another pathway involved in pTreg induction is antigen presentation by immature DCs. Notably, it has been shown that delivering peptides in subimmunogenic forms for a prolonged period of time can result in the induction of $\mathrm{CD} 4{ }^{+} \mathrm{CD} 25^{+}$Tregs from naïve $\mathrm{T}$ cells in peripheral lymphoid organs, even in the absence of a functional thymus (68).

\section{Treg HOMEOSTASIS}

It was thought that IL-2 is the most important Treg regulator, being required for both Treg maintenance and function $(69,70)$. More recently, it was shown that Tregs form two distinct populations, the $\mathrm{CD} 44^{\text {lo }} \mathrm{CD} 62 \mathrm{~L}^{\text {hi }}$ central Tregs, which actively recirculate through lymphoid organs and are sustained by paracrine IL-2, and the CD44 $4^{\text {hi }}$ CD62 $L^{\text {lo }}$ CCR7 $^{\text {lo }}$ effector Tregs, which are not found in the lymphoid tissue, do not require IL-2, and are instead maintained by inducible costimulator (ICOS) (71). In vivo, Tregs can proliferate in response to antigens, meaning that Tregs can dynamically respond to their environment (72). It has also been shown that B7/CD28 costimulation plays a critical role in maintenance of Tregs, as shown by experiments reporting a profound decrease in Tregs in B7/CD28-deficient mice $(58,73)$.

\section{Tregs IN THE LYMPH NODES}

L-selectin (CD62L) is thought to be crucial for the homing of Tregs to the lymph nodes (LNs). CD4 ${ }^{+} \mathrm{CD} 25^{+} \mathrm{CD} 62 \mathrm{~L}^{+}$Tregs more potently suppress the proliferative responses of $\mathrm{CD} 25^{\text {neg }}$ $\mathrm{CD}^{+} \mathrm{T}$ cells than $\mathrm{CD} 4^{+} \mathrm{CD} 25^{+} \mathrm{CD}^{2} \mathrm{~L}^{\text {neg }}$ Tregs (74). CD62Ldependent homing induced survival and tolerance in a vascularized cardiac allograft mouse (75). It has therefore been postulated that Treg trafficking to the LNs may be dependent on CD62L (76). A CD $69^{\text {neg }} \mathrm{CD} 25^{+} \mathrm{CD} 4^{+} \mathrm{T}$-cell subset from the LNs was identified

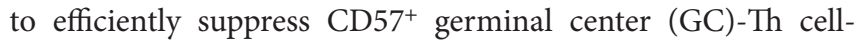
driven $\mathrm{B}$ cell production of immunoglobulins. These cells express
CCR7 and efficiently migrate in response to CCL19, a chemokine expressed in the T cell zone of LNs. Furthermore, many of these $\mathrm{CD}^{\text {neg }}{ }^{\text {ne }} 25^{+} \mathrm{CD} 4^{+} \mathrm{T}$-cells populate the $\mathrm{T}$ cell rich zone of the LNs; however, some are present in the GCs also (77).

A particular subset of Tregs, the $\mathrm{T}$ follicular regulatory cells (Tfr), discovered in 2011, are Tregs that have migrated into the LN, and thus share phenotypes with Tregs, such as FoxP3, CTLA-4 (cytotoxic T-lymphocyte antigen 4), and CD25 expression (78). Additionally, they undergo differentiation and share surface markers with $\mathrm{T}$ follicular helper cells (Tfh), such PD-1 and ICOS, and important for their localization in the GC s, Bcl6, CXCR5, and CXCL13 (78). This phenotype allows them to modulate B cell and Tfh cell functions in the LN follicles and acts as immune regulators of the GC responses to stimulation $(43,78-80)$. Currently, CTLA-4 is the only molecule demonstrated to be necessary for full suppression $(81,82)$; however, IL- 10 and TGF- $\beta 1$ are theorized to play roles in the suppressive function (83). Although a small subpopulation of mature $\mathrm{Tfr}$ do not express CD25 (84), depletion of Tfr by anti-CD25 mAb still enhanced humoral responses, with significantly more $\mathrm{Ab}$ produced $(85,86)$.

Soon after their migration to the LNs, Tregs form long-lasting conjugates with DCs. This prevents the DCs from interacting with $\mathrm{CD} 25^{\text {neg }} \mathrm{CD} 4^{+} \mathrm{T}$ helper cells (87). Using a murine mathematical model, it has been shown that after occupying the LNs, Tregs do not recirculate, whereas naïve T cells do so readily (88).

\section{MECHANISMS OF Treg SUPPRESSION}

$\mathrm{T}$ regulatory cells produce multiple secretory cytokines that mediate their suppressive activities. The conventional dogma is that cell-to-cell contact is required for the Tregs to exert their suppressive activities (89). However, advances in cell culture capabilities have recently challenged this paradigm. A study using Treg separation from $\mathrm{CD}^{+} \mathrm{T}$ cells with a $0.45-\mu \mathrm{m}$ permeable membrane demonstrated that, while cell-to-cell contact in the presence of IL-10 and IL-35 appears to indeed be required for Treg activation, the suppressive capabilities of Tregs are not completely mediated by cell contact. Instead, the release of inhibitory factors, such as TGF- $\beta$, IL-10, and IL-35, plays a prominent role in Treg-mediated suppression $(44,45)$.

Transforming growth factor beta- 1 is a cytokine secreted by Tregs, which is also present on the cell surface as a membrane bound cytokine. TGF- $\beta 1$ suppresses non-Treg cells through interactions with the two heterodimer TGF- $\beta$ receptors, TGF- $\beta$ RI and TGF- $\beta$ RII $(90,91)$. In fact, through the use of T cell-specific $T g f b 1$ deletion and subsequent Treg cotransfer experiments in Rag1 $^{-/-}$mice, the inhibition of Th1 differentiation and colitis was shown to be dependent upon TGF- $\beta 1$ production by Tregs (46). Additional studies with TGF- $\beta 1$ blockades have further supported its role as a mediator of Treg suppressive function $(47,48)$. TGF- $\beta 1$ primarily inhibits type 1 T-helper cell (Th1) responses by blocking differentiation through the inhibition of the master regulator T-bet. However, TGF- $\beta 1$ is also able to directly suppress the effector functions of $\mathrm{CD}^{+} \mathrm{T}$ cells through inhibiting cytokine and effector molecule secretion (49). Beyond direct suppression, TGF- $\beta$ signaling is important for inducing 
Treg trafficking to the gut, where they can then modulate gut Th17 cells and gut inflammation (50).

T regulatory cells also produce IL-10, which has been shown to be important in controlling inflammation, as disruption of IL-10 production caused colitis in mice. However, unlike TGF- $\beta 1$, the lack of Treg-produced IL-10 does not cause systemic immunopathology, as demonstrated through Treg-specific IL-10 deletions by Cre recombinase. On the contrary, these mice present with contained pathology to the colon, lung, and skin, indicating a tissue-specific mechanism of IL-10 immune suppression (92). Nonetheless, IL-10 has been linked to Treg activation and their effector functions (45), thus playing a critical role in immune control.

The new IL-12 family heterodimer IL-35 (Ebi3-IL-12 $\alpha$ ) is an inhibitory molecule produced by Tregs, which is required for complete suppressive functionality in mice (51). In fact, both parts of IL-35, Ebi3 and IL-12 $\alpha$, are necessary to support T-cell proliferation, and recombinant IL-35 was sufficient for reduction of effector T-cell proliferation (51). Tregs are capable of inducing differentiation of naïve T cells to “iT(R)35” cells (93) through IL-10 and IL-35. These iT(R)35 cells have impressive suppressive capabilities originating from substantially increased IL-35 production, while they lack FoxP3 and do not produce TGF- $\beta$ or IL10, making them a population distinct from tTregs (93). However, other studies questioned the importance of IL-35 and demonstrated that IL-35 is not constitutively expressed on human Tregs, while being shown to be produced by effector T cells (94).

On the cell surface, Tregs constitutively express CTLA-4, an inhibitory receptor that ablates CD28 costimulation by competitive binding of the B7-1 and B7-2 ligands (CD80 and CD86) on APCs $(11,12)$. Additionally, CTLA-4 also acts through upregulation of indoleamine 2,3-dioxygenase (IDO) production by DCs, inhibiting T cell expansion (95). The importance of this protein is clearly demonstrated by the observation that mice deficient in CTLA-4 die within 2-3 weeks from major organ lymphocytic infiltration and destruction, resulting from uncontrolled lymphocyte proliferation (13). A similar fatal autoimmune disease occurs if CTLA-4 is deleted from Tregs using Cre/lox with the FoxP3 promoter, due to loss of Treg suppressive function, particularly, lack of Treg-mediated DC CD80 and CD86 expression (14). Meanwhile, CTLA-4 blockade can induce autoimmune disease (96). Further support for the suppressive function of CTLA-4 through B7-1/B7-2 was obtained by demonstrating that reversal of the lymphoproliferative phenotype occurs after the administration of the CTLA4Ig, which mimics the ablation of CD28 costimulation by CTLA-4 (97). Imaging of conventional $\mathrm{CD}^{+} \mathrm{T}$ cells, DCs, and Tregs in the LNs showed that CTLA-4 blockade increases the amount of $\mathrm{CD} 4^{+} \mathrm{T}$ cell-DC interactions and T-cell activation through ablation of suppressive interactions of both B7-1 and B7-1 on DCs (98). However, CTLA-4 does not act exclusively through Tregs, being also expressed on conventional $\mathrm{T}$ cells, where inhibitory function can occur in cis by both the previously stated mechanism, as well as by signaling through the cytoplasmic region (99). CTLA-4 is also an important contributor to Treg survival, as the anti-CTLA-4 $\mathrm{mAb}$ Ipilimumab was found to have an additional function of targeting Tregs for death by $\mathrm{CD}_{16}{ }^{+}$nonclassical macrophages through antibody-dependent cell-mediated cytotoxicity (ADCC) (100).

An indirect Treg suppression mechanism is through consumption of IL-2. CD $4^{+} \mathrm{CD} 25^{+}$Tregs are able to bind IL-2, preventing non-Tregs from binding and thus inhibiting activation (101), while simultaneously depriving them of the necessary prosurvival signals to prevent apoptosis (102). This competition serves an additional function of enhancing Treg responses by priming them for IL-10 production after TCR stimulation $(103,104)$.

Extracellular adenosine triphosphate (ATP) is a known inflammatory signal that acts through the P2 purinergic receptors and is released from cells, which have a high intracellular concentration of ATP, during tissue damage [reviewed in Ref. (105)]. Tregs suppress the inflammatory responses to ATP through directly limiting the amount of extracellular ATP by hydrolysis of ATP to adenosine monophosphate (AMP) by CD39, which is highly expressed on the surface of FoxP3 ${ }^{+}$Tregs (33) and is further upregulated during inflammation (106). Indeed, CD39 plays an important role during HIV infection, as suggested by the observations that CD39+ Treg cells are inversely correlated with $\mathrm{CD}^{+} \mathrm{T}$ cell counts (107) and polymorphisms that cause decreased expression of CD39 correlate with slower disease progression (107) and decreased suppression of effector T cells (106). Following hydrolysis, AMP is hydrolyzed to adenosine by CD73 on the surface of Tregs $(108,109)$, which is then shed from the plasma membrane (110). This further increases the suppressive nature of Tregs as adenosine is an anti-inflammatory molecule. In vitro experiments demonstrated that adenosine directly inhibits $\mathrm{T}$ cell activation and proliferation through binding to the receptor $\mathrm{A}_{2 \mathrm{a}}$, preventing TCR-mediated IL-2R (111) and IFN- $\gamma$ (112) expression. Adenosine further inhibits the Th 1 response by decreasing TNF- $\alpha$ and IL- 12 production by myeloid dendritic cells (mDCs) while simultaneously increasing IL-10 (113). Additionally, adenosine inhibits IFN- $\gamma$ and IL- 2 production of $\mathrm{CD}^{+}$and $\mathrm{CD}^{+} \mathrm{T}$ cells and is inversely correlated to gut inflammation and damage during SIV infection (34). Tregs also suppress T cells through cyclic AMP (cAMP). The binding of adenosine to receptors $A_{2 A}$ and $A_{2 B}$ induces adenylate cyclases, increasing the production of intracellular cAMP and suppressing the immune activation [reviewed in Ref. (114)]. Using gap junction inhibitors and cAMP antagonists, it was shown that Tregs transfer cAMP through gap junctions to suppress non-Tregs (115-117).

\section{ROLE OF Tregs IN HIV/SIV INFECTION}

\section{Changes in Treg Frequency Throughout HIV/SIV Infection}

Treg suppression of the cell-mediated immune response occurs early during the acute HIV/SIV infection, as reported in SIVinfected Rhesus macaques (RMs) (118). In fact, in HIV-infected individuals, the relative frequency of Tregs correlates with the viral load levels and disease progression (119-123), while being inversely correlated with the SIV-specific cytotoxic T lymphocyte (CTL) responses (118). Of note, $\mathrm{CD}^{+} \mathrm{T}$ cell depletion 
characteristic to acute HIV/SIV infection partially spares Tregs, as suggested by the observation that, in spite of the decrease in their absolute counts, Treg frequency increases during the acute HIV infection (121, 123-125). In HIV-infected subjects receiving ART, Treg frequency is partially restored $(120,126)$. Interestingly, elite controllers have higher Treg absolute counts, yet lower frequencies, in the peripheral blood and rectal mucosa compared to progressors $(119,127)$. The mechanism by which Tregs are spared relative to other $\mathrm{CD}^{+}$cell subsets during HIV infection remains unclear. In the gut mucosa of SIV-infected RMs, non-Tregs were shown to have significantly higher apoptotic gene expression than Tregs, of which some were apoptotic genes associated with HIV production, supporting the concept that Tregs are relatively resistant to cell death mediated by SIV infection (128). This relative Treg resistance to HIV/SIV infection is further supported by the observations that the number of infected Tregs is similar to $\mathrm{CD}^{+} \mathrm{CD} 25^{\text {neg }}$ cells (129) and that HIV gp120 binding to CD4 enhances Treg survival $(122,130)$.

Alternatively, the increases in Treg frequency may also be explained by increased conversion of peripheral conventional $\mathrm{CD}^{+} \mathrm{T}$ cells to a pTreg phenotype. Ex vivo work performed with plasmacytoid dendritic cells ( $\mathrm{pDCs}$ ) and conventional $\mathrm{CD}^{+}{ }^{+} \mathrm{T}$ cells from HIV-infected individuals demonstrated enhanced induction of Treg differentiation when pDCs were stimulated with HIV (131). Similarly, tissue mDCs from SIVinfected NHPs were more efficient at converting non-Tregs to Tregs (132). Increases in the levels of TGF- $\beta$ characteristic to pathogenic SIV infection of RMs (133) further substantiate the theory of increased pTreg conversion during HIV/SIV infection. This finding is important, because in progressors, Treg suppressive capacity is maintained throughout infection (134), with enhanced function in the LNs, where there is a HIV/ SIV reservoir of importance, compared to the peripheral blood (135-137).

In the LNs, Tfr contribute to the impairment of Tfh function (138, 139). Tfh expand during HIV infection (140-142). Their increase is associated with B cell dysfunction (143), as documented by hypergammaglobulinemia, increased GC B cells, and decreased memory B cells (140-142, 144), a likely consequence of hyperactivation through chronic antigenic stimulation (144) and increased cytokine production (141, 142). During HIV infection, the Tfh/Tfr ratio increases and is associated with impaired somatic hypermutation and affinity maturation. These functions can be restored upon Tfr reconstitution (145). While the frequency of Tfr relative to total $\mathrm{CD} 4^{+} \mathrm{T}$ cells increases during chronic SIV infection, the Tfr fraction of Tfh is decreased during both acute and chronic stages. Loss of Tfh proliferation control by Tfr during HIV/SIV infection has been examined as a possible explanation for Tfh expansion and may help explain the hyperactivation in the B cell follicles $(146,147)$. Other studies, however, reported opposite findings, showing that the Tfr/ Tfh ratio increases postinfection and through expansion of the regulatory phenotype (139). These data are consistent with Tfh impairment, notably downregulation of ICOS and decreased expression of IL-21 and IL-4 (139), implicating Tfh inhibition in the aberrant humoral response. Thus, whether therapeutic targeting of Tfr in HIV/SIV infection is beneficial or detrimental is still up for debate, although their permissiveness to infection enhances the beneficial aspects of targeting Tfr (148).

\section{Treg Suppression in HIV Infection}

$\mathrm{T}$ regulatory cells are considered both beneficial and detrimental during acute HIV infection (Figure 1). Increased immune activation is a hallmark of HIV infection, and Tregs have been shown to control the activation status of HIV-infected CD4 ${ }^{+}$ $\mathrm{T}$ cells $(118,149-152)$. In the nonpathogenic SIV infection of African green monkeys, an increase in Tregs occurs early during the acute infection, as early as $24 \mathrm{~h}$ postinfection, concomitant with significant increases in TGF- $\beta$ and IL-10 (153). In contrast, during the acute pathogenic SIV infection of RMs, there is only modest TGF- $\beta$ induction and delayed increases in IL-10 (153). Additional support for the role of Tregs in acute infection was obtained by Cecchinato et al. who showed that CTLA-4 blockade early during the acute infection was detrimental to RMs, resulting in increased viral replication and decreased responsiveness to ART (154). These results may be due to essentially "adding fuel to the fire" by increasing immune activation and consequently expanding the target pool for SIV, although some of this may be due to non-Treg effects. In vitro studies have shown that, in addition to limiting the amount of susceptible cells, Tregs can limit the infection of conventional $\mathrm{CD}^{+}{ }^{+} \mathrm{T}$ cells through DC-CD $4^{+} \mathrm{T}$ cell immunological synapses (117). Therefore, Tregs can help in preventing the deleterious pathogenic consequences of HIV/SIV infections by controlling the immune activation status of virus producing cells by shifting them into resting state. This thereby suppresses viral production, and prevents the spread of infection. The corollary of this paradigm is, however, that, by pushing infected $\mathrm{T}$ cells into a resting state, Tregs are promoting the generation of the latent HIV/SIV reservoir, the seeding of which starts as early as 3 days post-infection (155), which represents the ultimate obstacle for HIV cure research.

Meanwhile, Tregs also suppress the HIV-specific $\mathrm{CD}^{+} \mathrm{T}$ cell responses (156), their frequency being inversely correlated with the SIV-specific CTL response (118) and T-cell activation (125). The disruption of the cell-mediated immune response against HIV by Treg-mediated suppression of $\mathrm{CD}^{+} \mathrm{T}$ cytotoxic lymphocytes is therefore inhibiting viral clearance in infected individuals, likely leading to an increased viral replication. In fact, in controllers with the protective $H L A-B^{\star} 27$ and $H L A-B{ }^{\star} 57$ alleles, the $H L A-B^{\star} 27$ and $H L A-B^{\star} 57$-restricted $\mathrm{CD} 8^{+} \mathrm{T}$ cells are not suppressed by Tregs, whereas the $\mathrm{CD}^{+} \mathrm{T}$ cells with nonprotective HLA alleles are highly suppressed ex vivo, substantiating the role $\mathrm{CD}^{+} \mathrm{T}$ cells in controlling virus (157). Jiang et al. infected humanized mice with HIV following Treg depletion and compared them with those that were not depleted of Tregs. They found that the Treg-depleted mice had lower levels of infection, as measured by peak viral loads and p24 intracellular staining in plasma and lymphoid tissues, such as spleen and mesenteric LNs (158), supporting a negative effect of Tregs on disease.

Of note, conflicting data were published with regard to the effect of Treg infection with HIV on their suppressive capabilities. Purified bulk Treg populations from HIV-infected individuals retain their suppressive activity $(125,149,159)$. In vitro, HIV 


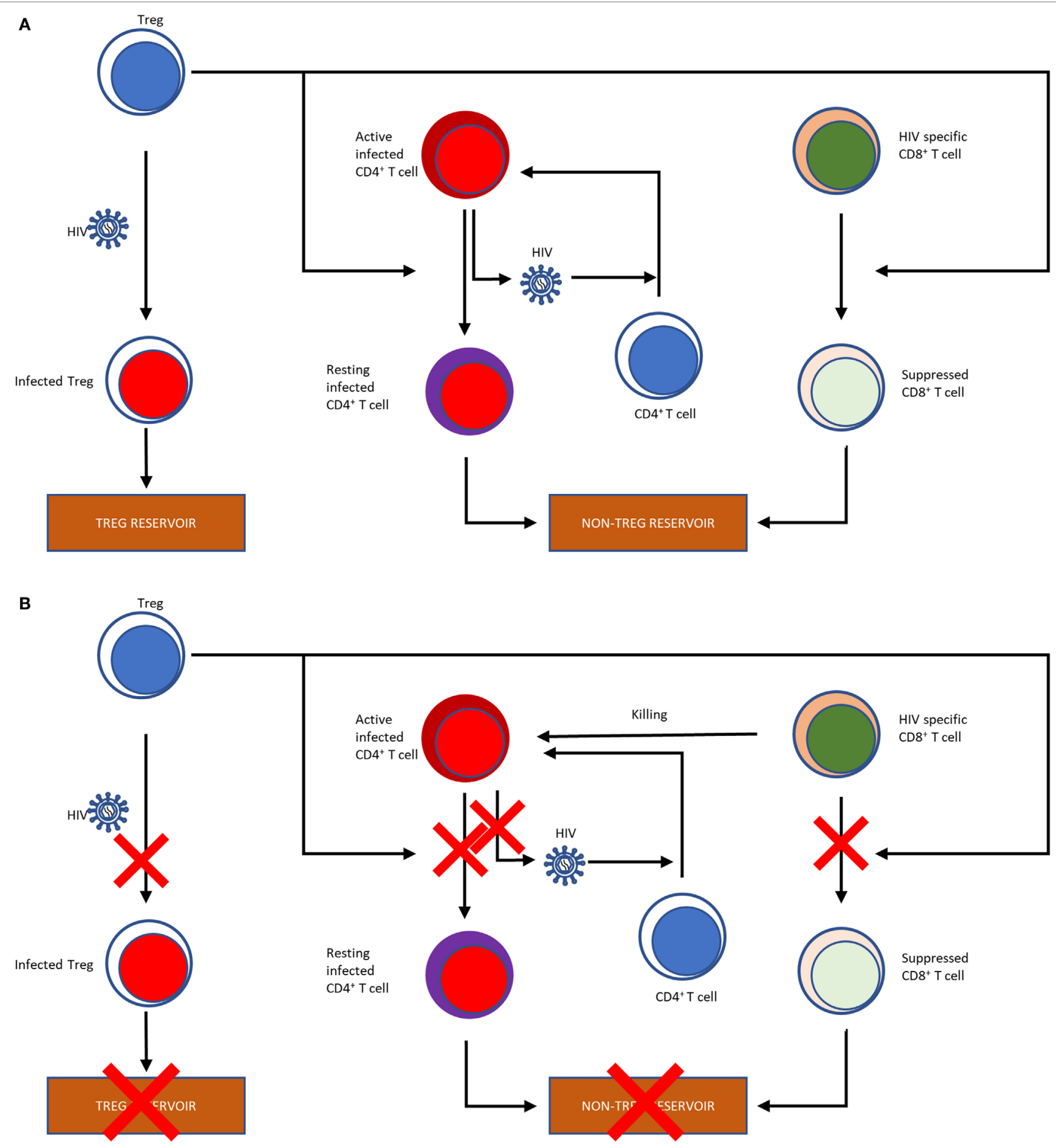

FIGURE 1 | Flow chart illustrating the effects of Tregs on the HIV reservoir (A). Tregs can be infected with HIV, thereby contributing to the HIV reservoir. Tregs reverse the activation status of the HIV-infected T cells into resting T cells, further contributing to the reservoir formation. Finally, by suppressing the HIV-specific CD8 ${ }^{+}$ T cells, which would otherwise kill infected cells, Tregs also shape the non-Treg reservoir. Potential effects of Treg depletion on the HIV reservoir (B). Treg depletion obviously result in a reduction of the Treg reservoir through direct killing. Treg depletion also abolish their suppressive effects of the T cells, which may reverse their resting status, become activated and produce and release the virus. Finally, reversion of the suppressive effect of Tregs on HIV-specific CD8 ${ }^{+} \mathrm{T}$ cells has the potential to boost their anti-SIV activity, which can also curtail the reservoir.

infection of Tregs has been reported to either have no effect on Treg functionality (160) or result in loss of functionality (161). However, when functionality was assessed on a per-cell basis, infected Tregs had a lower suppressive capacity and corresponding decreases in genes relating to suppressive function and increases in inhibitory genes compared to noninfected Tregs 
(162), and this altered suppressive capacity may further contribute to the generalized immune activation in chronic infection.

\section{Tregs AS AN HIV/SIV RESERVOIR}

Suppression of the immune responses is not the only way that Tregs contribute to HIV disease. Treg infection with both SIV $(118,128)$ and HIV (160) occurs both in vitro (163) and in vivo. Indeed, when naïve $\mathrm{T}$ cells were transduced to express FoxP3, their susceptibility to HIV infection increased, and they produced infectious virus at levels comparable to memory $\mathrm{T}$ cells (163). In SIV-infected macaques, the fraction of mucosal Tregs containing SIV DNA is higher than that of the non-Tregs, but Tregs harbor less SIV RNA, which was interpreted as an indication that they are less susceptible to productive infection (128). Additionally, mucosal Tregs have a better survival rate than the non-Tregs, supporting increased infection rates without active replication (128). Similarly, in HIV-infected individuals, a larger proportion of Tregs contains HIV DNA than the non-Tregs and importantly, treatment with the histone deacetylase inhibitor (HDACi) valproic acid was able to reverse latency in resting Tregs from more patients than treatment of non-Tregs (164). Yet, when the comparisons are refined by comparing Tregs $\left(\mathrm{CD} 25^{+}\right.$ $\left.\mathrm{CD} 127^{\text {neg }}\right)$ to effector memory T cells (TEM) $\left(\mathrm{CD} 25^{\text {neg }} \mathrm{CD} 127^{+}\right)$, the difference in the levels of integrated HIV DNA between the two cellular populations was no longer significant (160), an unsurprising, but notable result due to the inclusion of naïve $\mathrm{T}$ cells in the non-Treg group. Interestingly, when comparing the in vitro susceptibility to infection, Tregs were reported to be more susceptible to infection by CXCR4-tropic strains, while TEM were more susceptible to CCR5-tropic strains (160). Further substantiating Tregs as an important reservoir, replication competent virus has been reactivated from Tregs isolated from HIV-infected individuals on long-term ART (164-166).

As such, due to the increase in Treg frequency during HIV/ SIV infection (118-126), a larger proportion of Tregs containing HIV/SIV DNA than non-Tregs $(128,164)$, better survival from SIV infection (128), and decreased suppressive activity of infected Tregs $(161,162)$, Tregs appear to be an important HIV reservoir. Together with their major role in shaping the viral reservoir, these data point to a key role for Tregs as targets in cure research strategies.

\section{TARGETING Tregs AS A CURE RESEARCH STRATEGY}

The suppressive function of Tregs during HIV infection has opened the forum to assess the benefit of manipulating Tregs for the HIV-infected subjects. However, this is not without its issues, as Tregs are also beneficial in some ways, particularly in suppressing general immune activation. The major problem with targeting Tregs is that the most typical marker for Tregs, the FoxP3 molecule is intracellular and, as such, it cannot be directly targeted in vivo. Multiple other targets have however been considered for in vivo Treg depletion strategies (summarized in Table 2).

TABLE 2 | Strategies for targeting T regulatory cells (Tregs) and/or their function.

\begin{tabular}{|c|c|c|c|c|c|c|}
\hline $\begin{array}{l}\text { Impact } \\
\text { on Tregs }\end{array}$ & Target & Drug & Rationale & $\begin{array}{l}\text { Expected Treg } \\
\text { depletion/blockade }\end{array}$ & Reference & $\begin{array}{l}\text { Potential } \\
\text { complications }\end{array}$ \\
\hline \multirow[t]{3}{*}{ Depletion } & CD25 & IL-2 immunotoxin & $\begin{array}{l}\text { Treg targeting through attachment } \\
\text { to CD25, the receptor for IL-2 } \\
\text { Treg killing through eEF-2 (Eukaryotic } \\
\text { elongation factor 2) ribosylation by } \\
\text { diphtheria toxin }\end{array}$ & $\begin{array}{l}\text { Up to } 75 \% \text { depletion of } \\
\text { circulating Tregs } \\
\text { Up to } 40 \% \text { depletion of } \\
\text { the lymph node }(L N) \text { Tregs }\end{array}$ & $(158,167,168)$ & $\begin{array}{l}\text { Autoimmunity, } \\
\text { toxicity }\end{array}$ \\
\hline & CCR4 & CCR4 immunotoxin & $\begin{array}{l}\text { Targets Tregs by attaching to CCR } 4 \\
\text { (effector Treg marker) } \\
\text { Treg killing through eEF-2 ribosylation } \\
\text { by diphtheria toxin }\end{array}$ & $\begin{array}{l}\text { Up to } 40 \% \text { depletion } \\
\text { of circulating Tregs } \\
\text { 9-22\% depletion } \\
\text { of the LN Tregs }\end{array}$ & $(173,174)$ & \\
\hline & & Cyclophosphamide & $\begin{array}{l}\text { Treg depletion through DNA double strand } \\
\text { breaks and decreased DNA repair. Treg } \\
\text { sensitivity is due to decreased production } \\
\text { of glutathione (required for detoxification } \\
\text { of Cy active metabolites) }\end{array}$ & $\begin{array}{l}\text { Up to } 50 \% \text { depletion } \\
\text { of circulating Tregs } \\
\text { Increased CD8 } 8^{+} \text {cell } \\
\text { and NK cell activation }\end{array}$ & $(177,178)$ & \\
\hline \multirow[t]{2}{*}{$\begin{array}{l}\text { Functional } \\
\text { blockade }\end{array}$} & CTLA-4 & Ipilimumab & $\begin{array}{l}\text { Binds to CTLA-4 on Tregs, blocking } \\
\text { it from inhibiting lymphocytes }\end{array}$ & $\begin{array}{l}\text { Up to } 75 \% \text { decrease } \\
\text { of circulating Tregs }\end{array}$ & $\begin{array}{l}(100,154 \\
179,180)\end{array}$ & $\begin{array}{l}\text { Autoimmunity, } \\
\text { toxicity }\end{array}$ \\
\hline & IDO & $\begin{array}{l}\text { 1-methyl-D- } \\
\text { tryptophan }\end{array}$ & $\begin{array}{l}\text { Inhibits IDO, blocking suppressive } \\
\text { function }\end{array}$ & $\begin{array}{l}\text { Increased expression of } \\
\text { IFN- } \gamma \text { by the lymphocytes } \\
\text { in the LNs, decreased } \\
\text { plasma viral loads }\end{array}$ & $(181,182)$ & Autoimmunity \\
\hline
\end{tabular}




\section{Targeting CD25 for Treg Depletion}

Two drugs targeting Treg through their constitutive expression of CD25, Daclizumab and Ontak, have been used to deplete them $(183,184)$. Both compounds bind CD25, but act differently. For Denileukin difitox (ONTAK), which is IL-2 coupled with diphtheria toxin, the IL-2 identifies and binds the CD25+ cells, allowing the diphtheria toxin to enter the cell and cause cell death by ADP-ribosylating host eEF-2 and preventing protein synthesis (185). Ontak has been used to treat CD25+ cutaneous T cell lymphoma (186). Ontak has also been tested with relatively positive results in peripheral T-cell lymphoma, metastatic renal cell carcinoma, and unresectable stage IV melanoma (187-189). Other studies of Ontak administration to melanoma patients, together with a DC vaccine reported no peripheral Treg depletion; yet, this result may be due to the use of a very low dose (190). In the same study, in vitro assessments showed that, while the internalization of Ontak was observable in activated Tregs even at low concentrations, Ontak internalization in resting Tregs only occurred at very high concentrations (190). This may be a potential barrier to the use of Ontak to target the resting reservoir.

The second component, Daclizumab, is a monoclonal antibody to CD25, which prevents the interaction of IL-2 with its receptor. As such, Daclizumab may be used for Treg depletion, as IL-2 is essential for Treg development, maintenance, and function, as discussed above. It has been approved for the treatment of relapsing forms of multiple sclerosis $(169,170)$ and in adult $\mathrm{T}$ cell leukemia to induce remission (191). Daclizumab was also used in radio-immunotherapeutic approaches, after linking it with ${ }^{90} \mathrm{Y}$, and its administration extended the length of remission in patients with adult $\mathrm{T}$ cell leukemia (171). This conjugated Daclizumab was also tested in other $\mathrm{CD} 25^{+}$malignancies, with promising results, especially for patients with Hodgkin's disease (192). Finally, for a short time, it was used to prevent acute rejection in patients with kidney transplants (193).

In the context of HIV infection, these compounds look promising, with regards to reservoir control. Ontak administration to DKO-hu HSC mice, followed by infection with HIV-R3A, reduced the levels of Tregs in blood, spleen, and mesenteric LN and increased the expression of HLA-DR, a marker of immune activation, on $\mathrm{CD}^{+}$and $\mathrm{CD} 8^{+} \mathrm{T}$ cells. It nevertheless resulted in lower levels of HIV-1 present in the plasma and the lymphoid organs, during the acute stage of infection (158). Furthermore, Ontak administration to humanized NRG mice infected with HIV-1 and completely virologically suppressed by ART, resulted in viral reactivation in spleen and bone marrow. Cell-associated viral DNA levels did not change, indicating that the virions relapsed from the reservoir. The mice were maintained on ART, which prevented the reactivated virus to reinfect cells and, after virus control was achieved post-Ontak administration, the levels of cell-associated viral DNA were significantly decreased in the lymphoid tissue as compared to controls, with no significant change in total CD4 ${ }^{+} \mathrm{T}$ cells in the spleen and bone marrow (194).

Ontak administration to chronically SIVsab-infected African green monkeys, resulted in a significant Treg depletion and induced significant $\mathrm{CD}^{+}$and $\mathrm{CD}^{+} \mathrm{T}$ cell activation (167). Finally, Ontak administration to SIVsab-infected RMs, a model of spontaneous complete control of HIV infection $(195,196)$, resulted in the depletion of $75-85 \%$ of the peripheral Tregs, an 8 - to 10 -fold increase in immune activation of the peripheral $\mathrm{CD}^{+}$and $\mathrm{CD}^{+} \mathrm{T}$ cells and a boost of SIV-specific T cells (168). Furthermore, a relatively robust virus reactivation was observed, with plasma viral loads reaching up to $10^{3}$ viral RNA copies $/ \mathrm{mL}$ (from below 5 copies/mL before treatment).

These results suggested that Treg depletion is a plausible strategy for reducing the HIV reservoir in circulation and lymphoid tissues, while boosting effective cell-mediated immune responses (168). Ontak was discontinued for clinical use due to the production issues related to difficulties in the purification from the bacterial expression system. Daclizumab has also been discontinued. However, a new bivalent IL-2 immunotoxin was developed that showed increased potency when compared to the Ontak-like monovalent version (197). When it was used in human CD25+ HUT102/6TG tumor-bearing NSG mouse model, this bivalent immunotoxin was shown to significantly prolong survival of the mice in a dose-dependent manner (198).

\section{Targeting CCR4 for Treg Depletion}

T regulatory cells (Tregs) express a high level of CCR4 (199-201), which is the receptor for CC chemokines (MIP-1, RANTES, TARC, and MCP-1) and has been shown to be a coreceptor for HIV-1 (202). Wang et al. developed a diphtheria-toxin based anti-human CCR4 immunotoxin, which effectively binds to and cause protein synthesis inhibition in target cells. It prolongs the survival of tumor-bearing NOD/SCID IL-2 receptor $\gamma-/-$ (NSG) mice injected with human CCR4 ${ }^{+}$acute lymphoblastic leukemia cells, indicating the efficacy of this drug (173). When the drug was tested in NHPs, it depleted $\sim 80 \%$ of CCR $4^{+}$FoxP $3^{+}$ and $40 \%$ of FoxP $3^{+} \mathrm{CD}^{+} \mathrm{T}$ cells in the peripheral blood. In the LNs, although there was a decrease of $\sim 90 \%$ of CCR $4^{+}$FoxP $^{+}$ Tregs, overall FoxP $3^{+} \mathrm{CD}^{+} \mathrm{T}$ cells were decreased by only $9-22 \%$ (174). The anti-CCR4 monoclonal antibody, Mogamulizumab, also shows promise in treatment of peripheral T-cell lymphoma and cutaneous T-cell lymphomas like mycosis fungoides and Sezary syndrome, by depleting $\mathrm{CCR}^{+}$malignant cells and CCR4 ${ }^{+}$Tregs $(175,176)$.

\section{Cyclophosphamide}

Cyclophosphamide (Cy) is a well-established chemotherapeutic agent, which is widely used for the treatment of leukemias and lymphomas. In high doses, Cy acts as a nonselective cytoreductive agent, which directed its uses as part of a preparation regimen for allogeneic stem-cell transplantation (203) and in treatments for systemic lupus erythematosus (SLE) (204-206). In low, metronomic dosages, Cy retains its antitumor capabilities, with reduced side effects and improved clinical responses (207). In mice, low-dose Cy administration selectively and significantly depleted and reduced the functionality of Tregs (208, 209). In vitro, CTLs and T helper cells are more resistant to Cy cytotoxicity than Tregs (210). Treg selectivity has been attributed to decreased DNA repair, as demonstrated by the increased and sustained DNA intercross-linking, as well as increased and sustained phosphorylated histone 2AX. A different mechanism for sensitivity, decreased production of glutathione, a detoxifier 
for Cy and its active metabolites, was also evoked. Indeed, Tregs have decreased ATP levels, which abrogate glutathione production, thereby inducing hypersensitivity to Cy (211). Interestingly, CCR2 ${ }^{+}$Tregs are preferentially depleted in mice over CCR2 ${ }^{\text {neg }}$ Tregs. An analysis of the cell cycles demonstrated increased proliferation and activation in CCR2 ${ }^{+}$Tregs (212).

Patients treated with a single dose of $300 \mathrm{mg} / \mathrm{m}^{2}$ Cy experienced a $20 \%$ Treg decrease sustained for 25 days and a decrease in proliferation marker Ki-67, further substantiating the loss of Treg homeostatic proliferation (177). Further studies of Cy in humans showed that end-stage cancer patients treated with metronomic dosing of $100 \mathrm{mg}$ of Cy per day for 7 days for 4 weeks of on/off, such that the cumulative dose of $\sim 777 \mathrm{mg} / \mathrm{m}^{2}$ was split between 2 weeks with a week without treatment in between, had greater than $50 \%$ decrease in both relative frequency and absolute counts of Tregs at day 30 of treatment. Importantly, treatment caused an increase in $\mathrm{CD}^{+} \mathrm{T}$ cell and NK cell cytotoxicity, a requirement for adequate clearance of infected cells during HIV cure approaches. Interestingly, when the dose was increased to $200 \mathrm{mg} /$ day, the selective depletion of Tregs was ablated, underpinning the importance of the low dose for specific Treg targeting (178).

To be an effective therapy for HIV, Cy must be effective in depleting Tregs from the LNs, where there is a major viral reservoir. A study in mice showed that Cy treatment was beneficial in the LNs by selectively depleting the $\mathrm{CD}^{+}$lymphoid-resident DCs while sparing the skin-derived migratory DCs and pDCs in the LNs and spleen. This selective depletion in turn boosted antigen presentation and cytokine secretion by the mDCs and pDCs, with a reduction in Treg suppressive capabilities. These results were confirmed by an adoptive transfer of $\mathrm{CD}^{+}$ DCs, which abrogated the immune enhancement (213). When patients were treated with a single IV low-dose of $300 \mathrm{mg} / \mathrm{m}^{2} \mathrm{Cy}$, a less immunosuppressive environment compared to controls was observed in the LNs, including significant decreases in IL-10, IL-6, and VEGF (214). Altogether, these results demonstrate that Cy administration is effective in modulating Tregs from both the LNs and periphery.

Little is known about Cy as a therapeutic approach for HIV cure. In an HIV-positive patient with SLE, treatment with Cy induced an enormous burst in viral replication, with plasma viral loads peaking to $>1.3 \times 10^{7}$ copies $/ \mathrm{mL}$ and quickly returned to below detectable levels (215). Using escalating doses up to $1.6 \mathrm{~g} / \mathrm{m}^{2}$, Bartlett et al., monitored the effects of Cy on HIV DNA in LNs and PBMCs and plasma viral loads. They found no significant difference in the HIV DNA burden of LNs and PBMCs versus the control group, but, of note, plasma viral loads were not suppressed in these patients, with two subjects out of five admitting to nonadherence to ART (216). Thus, it is possible that the increase in plasma viral loads and lack of viral DNA clearance may have been due to nonadherence.

Based on these data and the impressive benefits of Cy during various cancer treatments, low-dose Cy could be an effective therapy to decrease HIV reservoir, through its Treg-depleting effect. However, further studies are necessary to detail the potential of Cy to enhance HIV-specific CTL responses and/or reactivate latent $\mathrm{HIV}$.

\section{THERAPIES TARGETING Treg FUNCTION}

Various therapies to affect Treg function have also been tested. CTLA $-4^{+} \mathrm{PD}-1^{\text {neg }} \mathrm{CD} 4^{+} \mathrm{T}$ cells from multiple tissues are enriched for replication-competent SIV in infected RMs under ART, suggesting a potential therapeutic target for reservoir elimination (217). During HIV infection, CTLA-4 plays a role in suppression of HIV-specific T cells, with CTLA-4 blockade enhancing $\mathrm{CD}^{+} \mathrm{T}$ cell functionality, i.e., IFN- $\gamma$ production and cell proliferation $(218,219)$. In an HIV-infected individual treated with Ipilimumab ( $\alpha$-CTLA-4 mAb) for melanoma, plasma viral loads remained below the limit of detection using standard qPCR methods, whereas a general decline in plasma viral loads was seen when using the single copy assay, with an opposing increase in cell-associated unspliced RNA post-treatment, likely due to expansion of infected T cells (179). Additionally, in chronically infected RM given blocking CTLA-4 Ab while on ART, decreases in viral RNA was noted when therapy was interrupted, along with an increase in the SIV-specific immune response (180). However, when the same blockade was used in early infection with the pathogenic SIVmac251-infected RM model, it increased immune activation, viral replication, but did not augment SIV-specific responses, and abrogated responsiveness to ART (154). Thus, further studies need to be conducted to determine whether stand-alone CTLA- 4 blockade can be used as a latency reversing strategy.

As mentioned earlier, Tregs also express PD-1, which affected their homeostasis $(17,220)$. PD-1 also is thought to participate in Treg suppression (221). Due to its major role in contribution to T cell exhaustion $(222,223)$, efficiency of PD-1/PD-L1 blockade is widely studied in HIV-1 infection. However, the lack of specificity to Tregs of these interventions puts PD-1 targeting out of the scope of this review [reviewed in Ref. (224)].

Indoleamine 2,3-dioxygenase has been observed to increase during HIV infection and may suppress the antiviral responses (225). Thus, IDO blockade has been attempted to enhance the antiviral response to HIV/SIV $(181,182)$. In SIV-infected macaques under ART, treatment with the IDO inhibitor 1-methyl-D-tryptophan (D-1mT) reduced plasma viral loads and SIV RNA in LNs (181). D-1mT combined with CTLA-4 blockade in SIVmac251-infected macaques under ART did not provide better control of viremia (182). Additionally, this treatment induced acute pancreatitis in all animals, whereas the same ART regimen given alone induced pancreatitis in only $10-20 \%$ of the animals (182). These data suggest either an exacerbation of ART toxicity, or more likely, the induction of auto-immune responses against pancreatic antigens. Whatever the underlying mechanisms, such findings are a cautionary warning of the potential risk of any Treg manipulation in vivo.

\section{CONCLUSION}

Treg suppression of virus-specific immune responses may limit the efficacy of virus reactivation strategies, which require effective killing of the reactivated HIV/SIV reservoir. As a result, Tregs may play a central role in shaping the HIV reservoir and compromising the HIV/SIV-specific immune responses. Future research should 
focus on further refine the effects of various Treg manipulation techniques on the reservoir. Here, we have described several promising Treg treatments that may either suppress Treg activity or kill Tregs altogether. Treg depletion, which has the ability to directly target a small fraction of the reservoir, reactivate the virus, and boost cell-mediated immune responses, might be a desirable strategy for cure research. Although standalone Treg manipulations are promising, they can quite easily be added to other regimens. In the future, investigations into combining Treg therapies with the more traditional viral reactivation therapies, i.e., HDACis, PKA agonists, etc., or vaccinations may prove to be valid cure strategies.

\section{AUTHOR CONTRIBUTIONS}

Outlined the manuscript (AK, RS, IP, CC, CA); drafted the manuscript (AK, RS); reviewed the manuscript (IP, CC, CA); Overseen the process (CC, CA); prepared the figure (RS, AK).

\section{REFERENCES}

1. Gershon RK, Kondo K. Cell interactions in the induction of tolerance: the role of thymic lymphocytes. Immunology (1970) 18:723-37.

2. Sakaguchi S, Sakaguchi N, Asano M, Itoh M, Toda M. Immunologic selftolerance maintained by activated $\mathrm{T}$ cells expressing IL-2 receptor alphachains (CD25). Breakdown of a single mechanism of self-tolerance causes various autoimmune diseases. J Immunol (1995) 155:1151-64.

3. Lee HM, Bautista JL, Hsieh CS. Thymic and peripheral differentiation of regulatory T cells. Adv Immunol (2011) 112:25-71. doi:10.1016/B978-012-387827-4.00002-4

4. Zhang H, Kong H, Zeng X, Guo L, Sun X, He S. Subsets of regulatory T cells and their roles in allergy. J Transl Med (2014) 12:125. doi:10.1186/ 1479-5876-12-125

5. Mason GM, Lowe K, Melchiotti R, Ellis R, de Rinaldis E, Peakman M, et al. Phenotypic complexity of the human regulatory $\mathrm{T}$ cell compartment revealed by mass cytometry. J Immunol (2015) 195:2030-7. doi:10.4049/ jimmunol.1500703

6. Yagi H, Nomura T, Nakamura K, Yamazaki S, Kitawaki T, Hori S, et al. Crucial role of FOXP3 in the development and function of human CD25+CD4+ regulatory T cells. Int Immunol (2004) 16:1643-56. doi:10.1093/intimm/ dxh165

7. Brunkow ME, Jeffery EW, Hjerrild KA, Paeper B, Clark LB, Yasayko S-A, et al. Disruption of a new forkhead/winged-helix protein, scurfin, results in the fatal lymphoproliferative disorder of the scurfy mouse. Nat Genet (2001) 27:68. doi: $10.1038 / 83784$

8. Huter EN, Punkosdy GA, Glass DD, Cheng LI, Ward JM, Shevach EM. TGF $\beta$-induced FoxP3(+) regulatory T cells rescue scurfy mice. Eur J Immunol (2008) 38:1814-21. doi:10.1002/eji.200838346

9. Liu W, Putnam AL, Xu-Yu Z, Szot GL, Lee MR, Zhu S, et al. CD127 expression inversely correlates with FoxP3 and suppressive function of human CD4+ T reg cells. J Exp Med (2006) 203:1701-11. doi:10.1084/jem.20060772

10. Yu N, Li X, Song W, Li D, Yu D, Zeng X, et al. CD4+CD25+CD127low/T cells: a more specific Treg population in human peripheral blood. Inflammation (2012) 35:1773-80. doi:10.1007/s10753-012-9496-8

11. Mandelbrot DA, McAdam AJ, Sharpe AH. B7-1 or B7-2 is required to produce the lymphoproliferative phenotype in mice lacking cytotoxic T lymphocyte-associated antigen 4 (CTLA-4). J Exp Med (1999) 189:435-40. doi:10.1084/jem.189.2.435

12. Krummel MF, Allison JP. CTLA-4 engagement inhibits IL-2 accumulation and cell cycle progression upon activation of resting T cells. J Exp Med (1996) 183:2533-40. doi:10.1084/jem.183.6.2533

13. Tivol EA, Borriello F, Schweitzer AN, Lynch WP, Bluestone JA, Sharpe AH. Loss of CTLA-4 leads to massive lymphoproliferation and fatal multiorgan
$\mathrm{AK}$, and RS equally contributed to this manuscript. CC and CA are corresponding authors.

\section{ACKNOWLEDGMENTS}

We thank Drs. Nicolas Chomont and Jacob Estes for helpful discussion. This work was supported in part by the National Institutes of Health/National Institute of Environmental Health Sciences/National Institute of Diabetes and Digestive and Kidney Diseases/National Heart, Lung and Blood Institute/National Institute of Allergy and Infectious Diseases grants U01 ES029234 (CC), R01 AI119346 (CA), R01DK113919 (IP and CA), RO1 HL117715 (IP), R01 HL123096 (IP). AK was supported in part by the NIH Training Grant T32 AI060525. The funders had no role in study design, data collection and analysis, decision to publish, or preparation of the manuscript. This study is dedicated to the memory of Dr. Andrew A. Lackner dearest friend, mentor, and collaborator.

tissue destruction, revealing a critical negative regulatory role of CTLA-4. Immunity (1995) 3:541-7. doi:10.1016/1074-7613(95)90125-6

14. Wing K, Onishi Y, Prieto-Martin P, Yamaguchi T, Miyara M, Fehervari Z, et al. CTLA-4 control over Foxp3+ regulatory T cell function. Science (2008) 322:271-5. doi:10.1126/science.1160062

15. Guo F, Iclozan C, Suh W-K, Anasetti C, Yu X-Z. CD28 controls differentiation of regulatory $\mathrm{T}$ cells from naive CD4 T cells. J Immunol (2008) 181:2285-91. doi:10.4049/jimmunol.181.4.2285

16. Zhang R, Huynh A, Whitcher G, Chang J, Maltzman JS, Turka LA. An obligate cell-intrinsic function for CD28 in Tregs. JClin Invest (2013) 123:580-93. doi:10.1172/JCI65013

17. Asano T, Kishi Y, Meguri Y, Yoshioka T, Iwamoto M, Maeda Y, et al. PD-1 signaling has a critical role in maintaining regulatory $\mathrm{T}$ cell homeostasis; implication for Treg depletion therapy by PD-1 blockade. Blood (2015) 126:848-848.

18. Freeman GJ, Long AJ, Iwai Y, Bourque K, Chernova T, Nishimura H, et al. Engagement of the PD-1 immunoinhibitory receptor by a novel B7 family member leads to negative regulation of lymphocyte activation. J Exp Med (2000) 192:1027-34. doi:10.1084/jem.192.7.1027

19. Zhang B, Chikuma S, Hori S, Fagarasan S, Honjo T. Nonoverlapping roles of $\mathrm{PD}-1$ and FoxP3 in maintaining immune tolerance in a novel autoimmune pancreatitis mouse model. Proc Natl Acad Sci U S A (2016) 113:8490-5. doi:10.1073/pnas.1608873113

20. Vocanson M, Rozieres A, Hennino A, Poyet G, Gaillard V, Renaudineau S, et al. Inducible costimulator (ICOS) is a marker for highly suppressive antigen-specific $\mathrm{T}$ cells sharing features of TH17/TH1 and regulatory $\mathrm{T}$ cells. J Allergy Clin Immunol (2010) 126:280-9, 289.e1-7. doi:10.1016/j.jaci.2010. 05.022

21. Redpath SA, van der Werf N, Cervera AM, MacDonald AS, Gray D, Maizels RM, et al. ICOS controls Foxp3(+) regulatory T-cell expansion, maintenance and IL-10 production during helminth infection. Eur J Immunol (2013) 43:705-15. doi:10.1002/eji.201242794

22. Ito T, Hanabuchi S, Wang YH, Park WR, Arima K, Bover L, et al. Two functional subsets of FOXP3+ regulatory T cells in human thymus and periphery. Immunity (2008) 28:870-80. doi:10.1016/j.immuni.2008. 03.018

23. Do J-S, Visperas A, Sanogo YO, Bechtel JJ, Dvorina N, Kim S, et al. An IL-27/Lag3 axis enhances Foxp3(+) regulatory T cell suppressive function and therapeutic efficacy. Mucosal Immunol (2016) 9:137-45. doi:10.1038/ mi. 2015.45

24. Ronchetti S, Ricci E, Petrillo MG, Cari L, Migliorati G, Nocentini G, et al. Glucocorticoid-induced tumour necrosis factor receptor-related protein: a key marker of functional regulatory $\mathrm{T}$ cells. JImmunol Res (2015) 2015:171520. doi:10.1155/2015/171520 
25. Liao G, Nayak S, Regueiro JR, Berger SB, Detre C, Romero X, et al. GITR engagement preferentially enhances proliferation of functionally competent CD4+CD25+FoxP3+ regulatory T cells. Int Immunol (2010) 22:259-70. doi:10.1093/intimm/dxq001

26. Sun L, Jin H, Li H. GARP: a surface molecule of regulatory T cells that is involved in the regulatory function and TGF-beta releasing. Oncotarget (2016) 7:42826-36. doi:10.18632/oncotarget.8753

27. Tran DQ, Andersson J, Wang R, Ramsey H, Unutmaz D, Shevach EM. GARP (LRRC32) is essential for the surface expression of latent TGF-beta on platelets and activated FOXP3+ regulatory T cells. Proc Natl Acad Sci US A (2009) 106:13445-50. doi:10.1073/pnas.0901944106

28. Chen X, Wu X, Zhou Q, Howard OM, Netea MG, Oppenheim JJ. TNFR2 is critical for the stabilization of the CD4+Foxp3+ regulatory $\mathrm{T}$. cell phenotype in the inflammatory environment. J Immunol (2013) 190:1076-84. doi:10.4049/jimmunol.1202659

29. Takatori H, Kawashima H, Matsuki A, Meguro K, Tanaka S, Iwamoto T, et al. Helios enhances Treg cell function in cooperation with FoxP3. Arthritis Rheumatol (2015) 67:1491-502. doi:10.1002/art.39091

30. Sebastian M, Lopez-Ocasio M, Metidji A, Rieder SA, Shevach EM, Thornton AM. Helios controls a limited subset of regulatory T cell functions. J Immunol (2016) 196:144-55. doi:10.4049/jimmunol.1501704

31. Thornton AM, Kilaru G, Burr P, Rieder S, Muljo SA, Shevach EM. Helios expression defines two distinct populations of Foxp3+ regulatory $\mathrm{T}$ cells. J Immunol (2016) 196:125-6.

32. Singh K, Hjort M, Thorvaldson L, Sandler S. Concomitant analysis of helios and neuropilin-1 as a marker to detect thymic derived regulatory $\mathrm{T}$ cells in naïve mice. Sci Rep (2015) 5:7767. doi:10.1038/srep07767

33. Borsellino G, Kleinewietfeld M, Di Mitri D, Sternjak A, Diamantini A, Giometto R, et al. Expression of ectonucleotidase CD39 by Foxp3+ Treg cells: hydrolysis of extracellular ATP and immune suppression. Blood (2007) 110:1225-32. doi:10.1182/blood-2006-12-064527

34. He T, Brocca-Cofano E, Gillespie DG, Xu C, Stock JL, Ma D, et al. Critical role for the adenosine pathway in controlling simian immunodeficiency virus-related immune activation and inflammation in gut mucosal tissues. J Virol (2015) 89:9616-30. doi:10.1128/JVI.01196-15

35. Deaglio S, Dwyer KM, Gao W, Friedman D, Usheva A, Erat A, et al. Adenosine generation catalyzed by CD39 and CD73 expressed on regulatory T cells mediates immune suppression. J Exp Med (2007) 204:1257-65. doi:10.1084/ jem. 20062512

36. Sugiyama D, Nishikawa H, Maeda Y, Nishioka M, Tanemura A, Katayama I, et al. Anti-CCR4 mAb selectively depletes effector-type FoxP3+CD4+ regulatory T cells, evoking antitumor immune responses in humans. Proc Natl Acad Sci U S A (2013) 110:17945-50. doi:10.1073/ pnas. 1316796110

37. Curiel TJ, Coukos G, Zou L, Alvarez X, Cheng P, Mottram P, et al. Specific recruitment of regulatory $\mathrm{T}$ cells in ovarian carcinoma fosters immune privilege and predicts reduced survival. Nat Med (2004) 10:942-9. doi:10.1038/ nm1093

38. Lee I, Wang L, Wells AD, Dorf ME, Ozkaynak E, Hancock WW. Recruitment of Foxp3+ T regulatory cells mediating allograft tolerance depends on the CCR4 chemokine receptor. J Exp Med (2005) 201:1037-44. doi:10.1084/ jem.20041709

39. Yamazaki T, Yang XO, Chung Y, Fukunaga A, Nurieva R, Pappu B, et al. CCR6 regulates the migration of inflammatory and regulatory $\mathrm{T}$ cells. J Immunol (2008) 181:8391-401. doi:10.4049/jimmunol.181.12.8391

40. Schneider MA, Meingassner JG, Lipp M, Moore HD, Rot A. CCR7 is required for the in vivo function of CD4+ CD25+ regulatory T cells. J Exp Med (2007) 204:735-45. doi:10.1084/jem.20061405

41. Tosello V, Odunsi K, Souleimanian NE, Lele S, Shrikant P, Old LJ, et al. Differential expression of CCR7 defines two distinct subsets of human memory CD4+CD25+ Tregs. Clin Immunol (2008) 126:291-302. doi:10.1016/j. clim.2007.11.008

42. Cowan JE, McCarthy NI, Anderson G. CCR7 controls thymus recirculation, but not production and emigration, of Foxp3(+) T cells. Cell Rep (2016) 14:1041-8. doi:10.1016/j.celrep.2016.01.003

43. Chung Y, Tanaka S, Chu F, Nurieva RI, Martinez GJ, Rawal S, et al. Follicular regulatory $\mathrm{T}$ cells expressing Foxp3 and Bcl-6 suppress germinal center reactions. Nat Med (2011) 17:983-8. doi:10.1038/nm.2426
44. Collison LW, Pillai MR, Chaturvedi V, Vignali DAA. Regulatory T cell suppression is potentiated by target T cells in a cell contact, IL-35- and IL-10dependent manner. J Immunol (2009) 182:6121-8. doi:10.4049/jimmunol. 0803646

45. Strauss L, Bergmann C, Szczepanski M, Gooding W, Johnson JT, Whiteside TL. A unique subset of CD4+CD25highFoxp3+ T cells secreting interleukin-10 and transforming growth factor-betal mediates suppression in the tumor microenvironment. Clin Cancer Res (2007) 13:4345-54. doi:10.1158/10780432.CCR-07-0472

46. Li MO, Wan YY, Flavell RA. T cell-produced transforming growth factor- $\beta 1$ controls $\mathrm{T}$ cell tolerance and regulates Th1- and Th17-cell differentiation. Immunity (2007) 26:579-91. doi:10.1016/j.immuni.2007.03.014

47. Gil-Guerrero L, Dotor J, Huibregtse IL, Casares N, López-Vázquez AB, Rudilla $\mathrm{F}$, et al. In vitro and in vivo down-regulation of regulatory $\mathrm{T}$ cell activity with a peptide inhibitor of TGF- $\beta 1$. J Immunol (2008) 181:126-35. doi:10.4049/jimmunol.181.1.126

48. Shen E, Zhao K, Wu C, Yang B. The suppressive effect of CD25+Treg cells on Th1 differentiation requires cell-cell contact partially via TGF-beta production. Cell Biol Int (2011) 35:705-12. doi:10.1042/CBI20100528

49. Ahmadzadeh M, Rosenberg SA. TGF-beta 1 attenuates the acquisition and expression of effector function by tumor antigen-specific human memory CD8 T cells. J Immunol (2005) 174:5215-23. doi:10.4049/jimmunol.174. 9.5215

50. Konkel JE, Zhang D, Zanvit P, Chia C, Zangarle-Murray T, Jin W, et al. Transforming growth factor-beta signaling in regulatory $\mathrm{T}$ cells controls $\mathrm{T}$ helper-17 cells and tissue-specific immune responses. Immunity (2017) 46:660-74. doi:10.1016/j.immuni.2017.03.015

51. Collison LW, Workman CJ, Kuo TT, Boyd K, Wang Y, Vignali KM, et al. The inhibitory cytokine IL-35 contributes to regulatory T-cell function. Nature (2007) 450:566. doi:10.1038/nature06306

52. Wang J, Ioan-Facsinay A, van der Voort EI, Huizinga TW, Toes RE. Transient expression of FOXP3 in human activated nonregulatory CD4+ T cells. Eur J Immunol (2007) 37:129-38. doi:10.1002/eji.200636435

53. Jordan MS, Boesteanu A, Reed AJ, Petrone AL, Holenbeck AE, Lerman MA, et al. Thymic selection of CD4+CD25+ regulatory $\mathrm{T}$ cells induced by an agonist self-peptide. Nat Immunol (2001) 2:301. doi:10.1038/86302

54. Weissler KA, Caton AJ. The role of T-cell receptor recognition of peptide:MHC complexes in the formation and activity of Foxp3+ regulatory T cells. Immunol Rev (2014) 259:11-22. doi:10.1111/imr.12177

55. Toker A, Engelbert D, Garg G, Polansky JK, Floess S, Miyao T, et al. Active demethylation of the Foxp3 locus leads to the generation of stable regulatory T cells within the thymus. J Immunol (2013) 190:3180-8. doi:10.4049/ jimmunol.1203473

56. Ohkura N, Hamaguchi M, Morikawa H, Sugimura K, Tanaka A, Ito Y, et al. $\mathrm{T}$ cell receptor stimulation-induced epigenetic changes and Foxp3 expression are independent and complementary events required for Treg cell development. Immunity (2012) 37:785-99. doi:10.1016/j.immuni.2012. 09.010

57. Zhou P, Zheng X, Zhang H, Liu Y, Zheng P. B7 blockade alters the balance between regulatory $\mathrm{T}$ cells and tumor-reactive $\mathrm{T}$ cells for immunotherapy of cancer. Clin Cancer Res (2009) 15:960-70. doi:10.1158/1078-0432.CCR08-1611

58. Tang Q, Henriksen KJ, Boden EK, Tooley AJ, Ye J, Subudhi SK, et al. Cutting edge: CD28 controls peripheral homeostasis of CD4+CD25+ regulatory T cells. J Immunol (2003) 171:3348-52. doi:10.4049/jimmunol.171.7.3348

59. Cheng G, Yu A, Dee MJ, Malek TR. IL-2R signaling is essential for functional maturation of regulatory $\mathrm{T}$ cells during thymic development. J Immunol (2013) 190:1567-75. doi:10.4049/jimmunol.1201218

60. Fu S, Zhang N, Yopp AC, Chen D, Mao M, Chen D, et al. TGF- $\beta$ induces Foxp3 + T-regulatory cells from CD4 + CD25 - precursors. Am J Transplant (2004) 4:1614-27. doi:10.1111/j.1600-6143.2004.00566.x

61. Chen W, Jin W, Hardegen N, Lei K-J, Li L, Marinos N, et al. Conversion of peripheral CD4+CD25- naive $\mathrm{T}$ cells to $\mathrm{CD} 4+\mathrm{CD} 25+$ regulatory T cells by TGF- $\beta$ induction of transcription factor Foxp3. J Exp Med (2003) 198:1875-86. doi:10.1084/jem.20030152

62. Polansky JK, Kretschmer K, Freyer J, Floess S, Garbe A, Baron U, et al. DNA methylation controls Foxp3 gene expression. Eur J Immunol (2008) 38:1654-63. doi:10.1002/eji.200838105 
63. Coombes JL, Siddiqui KR, Arancibia-Cárcamo CV, Hall J, Sun CM, Belkaid Y, et al. A functionally specialized population of mucosal CD103+ DCs induces Foxp3+ regulatory $\mathrm{T}$ cells via a TGF-beta and retinoic acid-dependent mechanism. J Exp Med (2007) 204:1757-64. doi:10.1084/ jem.20070590

64. Mucida D, Park Y, Kim G, Turovskaya O, Scott I, Kronenberg M, et al. Reciprocal TH17 and regulatory T cell differentiation mediated by retinoic acid. Science (2007) 317:256-60. doi:10.1126/science.1145697

65. Xiao S, Jin H, Korn T, Liu SM, Oukka M, Lim B, et al. Retinoic acid increases Foxp3+ regulatory $\mathrm{T}$ cells and inhibits development of Th17 cells by enhancing TGF- $\beta$-driven Smad3 signaling and inhibiting IL- 6 and IL-23 receptor expression. J Immunol (2008) 181:2277-84. doi:10.4049/ jimmunol.181.4.2277

66. Bastien J, Plassat JL, Payrastre B, Rochette-Egly C. The phosphoinositide 3-kinase/Akt pathway is essential for the retinoic acid-induced differentiation of F9 cells. Oncogene (2005) 25:2040. doi:10.1038/sj.onc.1209241

67. Haxhinasto S, Mathis D, Benoist C. The AKT-mTOR axis regulates de novo differentiation of CD4+Foxp3+ cells. J Exp Med (2008) 205:565-74. doi:10.1084/jem.20071477

68. Apostolou I, von Boehmer H. In vivo instruction of suppressor commitment in naive T cells. J Exp Med (2004) 199:1401-8. doi:10.1084/jem.20040249

69. D'Cruz LM, Klein L. Development and function of agonist-induced CD25+Foxp3+ regulatory T cells in the absence of interleukin 2 signaling. Nat Immunol (2005) 6:1152-9. doi:10.1038/ni1264

70. Fontenot JD, Rasmussen JP, Gavin MA, Rudensky AY. A function for interleukin 2 in Foxp3-expressing regulatory T cells. Nat Immunol (2005) 6:1142-51. doi:10.1038/ni1263

71. Smigiel KS, Richards E, Srivastava S, Thomas KR, Dudda JC, Klonowski KD, et al. CCR7 provides localized access to IL-2 and defines homeostatically distinct regulatory T cell subsets. J Exp Med (2014) 211:121-36. doi:10.1084/ jem.20131142

72. Walker LS, Chodos A, Eggena M, Dooms H, Abbas AK. Antigen-dependent proliferation of CD4+ CD25+ regulatory T cells in vivo. J Exp Med (2003) 198:249-58. doi:10.1084/jem.20030315

73. Salomon B, Lenschow DJ, Rhee L, Ashourian N, Singh B, Sharpe A, et al. $\mathrm{B} 7 / \mathrm{CD} 28$ costimulation is essential for the homeostasis of the CD4+CD25+ immunoregulatory $\mathrm{T}$ cells that control autoimmune diabetes. Immunity (2000) 12:431-40. doi:10.1016/S1074-7613(00)80195-8

74. Fu S, Yopp AC, Mao X, Chen D, Zhang N, Chen D, et al. CD4+CD25+ CD62+ T-regulatory cell subset has optimal suppressive and proliferative potential. Am J Transplant (2004) 4:65-78. doi:10.1046/j.1600-6143.2003.00293.x

75. Ochando JC, Yopp AC, Yang Y, Garin A, Li Y, Boros P, et al. Lymph node occupancy is required for the peripheral development of alloantigen-specific Foxp3+ regulatory T cells. J Immunol (2005) 174:6993-7005. doi:10.4049/ jimmunol.174.11.6993

76. Wei S, Kryczek I, Zou W. Regulatory T-cell compartmentalization and trafficking. Blood (2006) 108:426-31. doi:10.1182/blood-2006-01-0177

77. Lim HW, Hillsamer P, Kim CH. Regulatory T cells can migrate to follicles upon T cell activation and suppress GC-Th cells and GC-Th cell-driven B cell responses. J Clin Invest (2004) 114:1640-9. doi:10.1172/JCI200422325

78. Linterman MA, Pierson W, Lee SK, Kallies A, Kawamoto S, Rayner TF, et al. Foxp3+ follicular regulatory $\mathrm{T}$ cells control the germinal center response. Nat Med (2011) 17:975-82. doi:10.1038/nm.2425

79. Wollenberg I, Agua-Doce A, Hernandez A, Almeida C, Oliveira VG, Faro J, et al. Regulation of the germinal center reaction by Foxp3+ follicular regulatory T cells. J Immunol (2011) 187:4553-60. doi:10.4049/ jimmunol.1101328

80. Alexander C-M, Tygrett LT, Boyden AW, Wolniak KL, Legge KL, Waldschmidt TJ. $\mathrm{T}$ regulatory cells participate in the control of germinal centre reactions. Immunology (2011) 133:452-68. doi:10.1111/j.1365-2567.2011.03456.x

81. Wing James B, Ise W, Kurosaki T, Sakaguchi S. Regulatory T cells control antigen-specific expansion of Tfh cell number and humoral immune responses via the coreceptor CTLA-4. Immunity (2014) 41:1013-25. doi:10.1016/j. immuni.2014.12.006

82. Sage PT, Alvarez D, Godec J, von Andrian UH, Sharpe AH. Circulating $\mathrm{T}$ follicular regulatory and helper cells have memory-like properties. J Clin Invest (2014) 124:5191-204. doi:10.1172/JCI76861

83. Sage PT, Sharpe AH. T follicular regulatory cells in the regulation of B cell responses. Trends Immunol (2015) 36:410-8. doi:10.1016/j.it.2015.05.005
84. Wing JB, Kitagawa Y, Locci M, Hume H, Tay C, Morita T, et al. A distinct subpopulation of $\mathrm{CD} 25-\mathrm{T}$-follicular regulatory cells localizes in the germinal centers. Proc Natl Acad Sci U S A (2017) 114:E6400-9. doi:10.1073/ pnas. 1705551114

85. Morgan ME, Sutmuller RP, Witteveen HJ, van Duivenvoorde LM, Zanelli E, Melief CJ, et al. CD25+ cell depletion hastens the onset of severe disease in collagen-induced arthritis. Arthritis Rheum (2003) 48:1452-60. doi:10.1002/ art. 11063

86. Eddahri F, Oldenhove G, Denanglaire S, Urbain J, Leo O, Andris F. CD4+ $\mathrm{CD} 25+$ regulatory $\mathrm{T}$ cells control the magnitude of $\mathrm{T}$-dependent humoral immune responses to exogenous antigens. Eur J Immunol (2006) 36:855-63. doi:10.1002/eji.200535500

87. Tang Q, Adams JY, Tooley AJ, Bi M, Fife BT, Serra P, et al. Visualizing regulatory $\mathrm{T}$ cell control of autoimmune responses in nonobese diabetic mice. Nat Immunol (2005) 7:83. doi:10.1038/ni1289

88. Milanez-Almeida P, Meyer-Hermann M, Toker A, Khailaie S, Huehn J. Foxp3+ regulatory T-cell homeostasis quantitatively differs in murine peripheral lymph nodes and spleen. Eur J Immunol (2015) 45:153-66. doi:10.1002/eji.201444480

89. Takahashi T, Kuniyasu Y, Toda M, Sakaguchi N, Itoh M, Iwata M, et al. Immunologic self-tolerance maintained by $\mathrm{CD} 25+\mathrm{CD} 4+$ naturally anergic and suppressive $\mathrm{T}$ cells: induction of autoimmune disease by breaking their anergic/suppressive state. Int Immunol (1998) 10:1969-80. doi:10.1093/ intimm/10.12.1969

90. Massague J, Andres J, Attisano L, Cheifetz S, Lopez-Casillas F, Ohtsuki M, et al. TGF-beta receptors. Mol Reprod Dev (1992) 32:99-104.

91. Nakamura K, Kitani A, Strober W. Cell contact-dependent immunosuppression by $\mathrm{Cd} 4+\mathrm{Cd} 25+$ regulatory $\mathrm{T}$ cells is mediated by cell surface-bound transforming growth factor $\beta$. J Exp Med (2001) 194:629-44. doi:10.1084/ jem.194.5.629

92. Rubtsov YP, Rasmussen JP, Chi EY, Fontenot J, Castelli L, Ye X, et al. Regulatory T cell-derived interleukin-10 limits inflammation at environmental interfaces. Immunity (2008) 28:546-58. doi:10.1016/j.immuni.2008. 02.017

93. Collison LW, Chaturvedi V, Henderson AL, Giacomin PR, Guy C, Bankoti J, et al. IL-35-mediated induction of a potent regulatory T cell population. Nat Immunol (2010) 11:1093. doi:10.1038/ni.1952

94. Bardel E, Larousserie F, Charlot-Rabiega P, Coulomb-L'Hermine A, Devergne O. Human CD4+CD25+Foxp3+ regulatory T cells do not constitutively express IL-35. J Immunol (2008) 181:6898-905. doi:10.4049/ jimmunol.181.10.6898

95. Mellor AL, Chandler P, Baban B, Hansen AM, Marshall B, Pihkala J, et al. Specific subsets of murine dendritic cells acquire potent $\mathrm{T}$ cell regulatory functions following CTLA4-mediated induction of indoleamine 2,3 dioxygenase. Int Immunol (2004) 16:1391-401. doi:10.1093/intimm/dxh140

96. Takahashi T, Tagami T, Yamazaki S, Uede T, Shimizu J, Sakaguchi N, et al. Immunologic self-tolerance maintained by $\mathrm{Cd} 25+\mathrm{Cd} 4+$ regulatory $\mathrm{T}$ cells constitutively expressing cytotoxic $\mathrm{T}$ lymphocyte-associated antigen 4 . J Exp Med (2000) 192:303-10. doi:10.1084/jem.192.2.303

97. Tivol EA, Boyd SD, McKeon S, Borriello F, Nickerson P, Strom TB, et al. CTLA4Ig prevents lymphoproliferation and fatal multiorgan tissue destruction in CTLA-4-deficient mice. J Immunol (1997) 158:5091-4.

98. Matheu MP, Othy S, Greenberg ML, Dong TX, Schuijs M, Deswarte K, et al. Imaging regulatory $\mathrm{T}$ cell dynamics and CTLA4-mediated suppression of T cell priming. Nat Commun (2015) 6:6219. doi:10.1038/ncomms7219

99. Carreno BM, Bennett F, Chau TA, Ling V, Luxenberg D, Jussif J, et al. CTLA-4 (CD152) can inhibit $\mathrm{T}$ cell activation by two different mechanisms depending on its level of cell surface expression. J Immunol (2000) 165:1352-6. doi:10.4049/jimmunol.165.3.1352

100. Romano E, Kusio-Kobialka M, Foukas PG, Baumgaertner P, Meyer C, Ballabeni $\mathrm{P}$, et al. Ipilimumab-dependent cell-mediated cytotoxicity of regulatory $\mathrm{T}$ cells ex vivo by nonclassical monocytes in melanoma patients. Proc Natl Acad Sci U S A (2015) 112:6140-5. doi:10.1073/pnas.1417320112

101. Thornton AM, Shevach EM. CD4+CD25+immunoregulatory $\mathrm{T}$ cells suppress polyclonal $\mathrm{T}$ cell activation in vitro by inhibiting interleukin 2 production. J Exp Med (1998) 188:287-96. doi:10.1084/jem.188.2.287

102. Pandiyan P, Zheng L, Ishihara S, Reed J, Lenardo MJ. CD4+CD25+Foxp3+ regulatory $\mathrm{T}$ cells induce cytokine deprivation-mediated apoptosis of effector CD4+ T cells. Nat Immunol (2007) 8:1353. doi:10.1038/ni1536 
103. de la Rosa M, Rutz S, Dorninger H, Scheffold A. Interleukin-2 is essential for CD4+CD25+ regulatory T cell function. Eur J Immunol (2004) 34:2480-8. doi:10.1002/eji.200425274

104. Barthlott T, Moncrieffe H, Veldhoen M, Atkins CJ, Christensen J, O'Garra A, et al. CD25+ CD4+ T cells compete with naive CD4+ T cells for IL-2 and exploit it for the induction of IL-10 production. Int Immunol (2005) 17: 279-88. doi:10.1093/intimm/dxh207

105. Cekic C, Linden J. Purinergic regulation of the immune system. Nat Rev Immunol (2016) 16:177. doi:10.1038/nri.2016.4

106. Rissiek A, Baumann I, Cuapio A, Mautner A, Kolster M, Arck PC, et al. The expression of $\mathrm{CD} 39$ on regulatory $\mathrm{T}$ cells is genetically driven and further upregulated at sites of inflammation. J Autoimmun (2015) 58:12-20. doi:10.1016/j.jaut.2014.12.007

107. Nikolova M, Carriere M, Jenabian M-A, Limou S, Younas M, Kök A, et al. CD39/adenosine pathway is involved in AIDS progression. PLoS Pathog (2011) 7:e1002110. doi:10.1371/journal.ppat.1002110

108. Langer D, Hammer K, Koszalka P, Schrader J, Robson S, Zimmermann H. Distribution of ectonucleotidases in the rodent brain revisited. Cell Tissue Res (2008) 334:199-217. doi:10.1007/s00441-008-0681-x

109. Kobie JJ, Shah PR, Yang L, Rebhahn JA, Fowell DJ, Mosmann TR. $\mathrm{T}$ regulatory and primed uncommitted CD4 T cells express CD73, which suppresses effector $\mathrm{CD} 4 \mathrm{~T}$ cells by converting $5^{\prime}$-adenosine monophosphate to adenosine. J Immunol (2006) 177:6780-6. doi:10.4049/jimmunol. 177.10 .6780

110. Mandapathil M, Hilldorfer B, Szczepanski MJ, Czystowska M, Szajnik M, Ren J, et al. Generation and accumulation of immunosuppressive adenosine by human CD4+CD25highFOXP3+ regulatory T cells. J Biol Chem (2010) 285:7176-86. doi:10.1074/jbc.M109.047423

111. Huang S, Apasov S, Koshiba M, Sitkovsky M. Role of A2a extracellular adenosine receptor-mediated signaling in adenosine-mediated inhibition of T-cell activation and expansion. Blood (1997) 90:1600-10.

112. Lappas CM, Rieger JM, Linden J. A2A adenosine receptor induction inhibits IFN- $\gamma$ production in murine CD4+ T cells. J Immunol (2005) 174:1073-80. doi:10.4049/jimmunol.174.2.1073

113. Panther E, Corinti S, Idzko M, Herouy Y, Napp M, la Sala A, et al. Adenosine affects expression of membrane molecules, cytokine and chemokine release, and the T-cell stimulatory capacity of human dendritic cells. Blood (2003) 101:3985-90. doi:10.1182/blood-2002-07-2113

114. Klein M, Bopp T. Cyclic AMP represents a crucial component of Treg cell-mediated immune regulation. Front Immunol (2016) 7:315. doi:10.3389/ fimmu.2016.00315

115. Bopp T, Becker C, Klein M, Klein-Hessling S, Palmetshofer A, Serfling E, et al. Cyclic adenosine monophosphate is a key component of regulatory T cell-mediated suppression. J Exp Med (2007) 204:1303-10. doi:10.1084/ jem.20062129

116. Moreno-Fernandez ME, Rueda CM, Rusie LK, Chougnet CA. Regulatory $\mathrm{T}$ cells control HIV replication in activated $\mathrm{T}$ cells through a cAMPdependent mechanism. Blood (2011) 117:5372-80. doi:10.1182/blood2010-12-323162

117. Moreno-Fernandez ME, Joedicke JJ, Chougnet CA. Regulatory T cells diminish HIV infection in dendritic cells - conventional CD4(+) T cell clusters. Front Immunol (2014) 5:199. doi:10.3389/fimmu.2014.00199

118. Estes JD, Li Q, Reynolds MR, Wietgrefe S, Duan L, Schacker T, et al. Premature induction of an immunosuppressive regulatory $\mathrm{T}$ cell response during acute simian immunodeficiency virus infection. J Infect Dis (2006) 193:703-12. doi:10.1086/500368

119. Schulze zur Wiesch J, Thomssen A, Hartjen P, Tóth I, Lehmann C, Meyer-Olson D, et al. Comprehensive analysis of frequency and phenotype of T regulatory cells in HIV infection: CD39 expression of FoxP3+ T regulatory cells correlates with progressive disease. J Virol (2011) 85:1287-97. doi:10.1128/JVI.01758-10

120. Presicce P, Orsborn K, King E, Pratt J, Fichtenbaum CJ, Chougnet CA. Frequency of circulating regulatory $\mathrm{T}$ cells increases during chronic HIV infection and is largely controlled by highly active antiretroviral therapy. PLoS One (2011) 6:e28118. doi:10.1371/journal.pone.0028118

121. Andersson J, Boasso A, Nilsson J, Zhang R, Shire NJ, Lindback S, et al. Cutting edge: the prevalence of regulatory $\mathrm{T}$ cells in lymphoid tissue is correlated with viral load in HIV-infected patients. J Immunol (2005) 174:3143-7. doi:10.4049/jimmunol.174.6.3143
122. Nilsson J, Boasso A, Velilla PA, Zhang R, Vaccari M, Franchini G, et al. HIV-1-driven regulatory T-cell accumulation in lymphoid tissues is associated with disease progression in HIV/AIDS. Blood (2006) 108:3808-17. doi:10.1182/blood-2006-05-021576

123. Suchard MS, Mayne E, Green VA, Shalekoff S, Donninger SL, Stevens WS, et al. FOXP3 expression is upregulated in $\mathrm{CD} 4(+) \mathrm{T}$ cells in progressive HIV-1 infection and is a marker of disease severity. PLoS One (2010) 5:e11762. doi:10.1371/journal.pone.0011762

124. Tsunemi S, Iwasaki T, Imado T, Higasa S, Kakishita E, Shirasaka T, et al. Relationship of CD4+CD25+ regulatory T cells to immune status in HIVinfected patients. AIDS (2005) 19:879-86. doi:10.1097/01.aids.0000171401. 23243.56

125. Eggena MP, Barugahare B, Jones N, Okello M, Mutalya S, Kityo C, et al. Depletion of regulatory T cells in HIV infection is associated with immune activation. J Immunol (2005) 174:4407-14. doi:10.4049/jimmunol. 174.7.4407

126. Epple HJ, Loddenkemper C, Kunkel D, Troger H, Maul J, Moos V, et al. Mucosal but not peripheral FOXP3+ regulatory $\mathrm{T}$ cells are highly increased in untreated HIV infection and normalize after suppressive HAART. Blood (2006) 108:3072-8. doi:10.1182/blood-2006-04-016923

127. Owen RE, Heitman JW, Hirschkorn DF, Lanteri MC, Biswas HH, Martin JN, et al. HIV(+) elite controllers have low HIV-specific T cell activation yet maintain strong, polyfunctional T cell responses. AIDS (2010) 24:1095-105. doi:10.1097/QAD.0b013e3283377ale

128. Allers K, Loddenkemper C, Hofmann J, Unbehaun A, Kunkel D, Moos V, et al. Gut mucosal FOXP3+ regulatory CD4+ T cells and nonregulatory CD4+ T cells are differentially affected by simian immunodeficiency virus infection in Rhesus macaques. JVirol (2010) 84:3259-69. doi:10.1128/ JVI.01715-09

129. Chase AJ, Yang H-C, Zhang H, Blankson JN, Siliciano RF. Preservation of FoxP3+ regulatory $\mathrm{T}$ cells in the peripheral blood of human immunodeficiency virus type 1-infected elite suppressors correlates with low CD4+ T-cell activation. J Virol (2008) 82:8307-15. doi:10.1128/JVI.00520-08

130. Becker C, Taube C, Bopp T, Becker C, Michel K, Kubach J, et al. Protection from graft-versus-host disease by HIV-1 envelope protein gp120mediated activation of human CD4+CD25+ regulatory T cells. Blood (2009) 114:1263-9. doi:10.1182/blood-2009-02-206730

131. Manches O, Munn D, Fallahi A, Lifson J, Chaperot L, Plumas J, et al. HIVactivated human plasmacytoid DCs induce Tregs through an indoleamine 2,3-dioxygenase-dependent mechanism. J Clin Invest (2008) 118:3431-9. doi:10.1172/JCI34823

132. Presicce P, Shaw JM, Miller CJ, Shacklett BL, Chougnet CA. Myeloid dendritic cells isolated from tissues of SIV-infected Rhesus macaques promote the induction of regulatory T-cells. AIDS (2012) 26:263-73. doi:10.1097/ QAD.0b013e32834ed8df

133. Estes JD, Wietgrefe S, Schacker T, Southern P, Beilman G, Reilly C, et al. Simian immunodeficiency virus-induced lymphatic tissue fibrosis is mediated by transforming growth factor $\beta 1$-positive regulatory $\mathrm{T}$ cells and begins in early infection. J Infect Dis (2007) 195:551-61. doi:10.1086/510852

134. Shaw JM, Hunt PW, Critchfield JW, McConnell DH, Garcia JC, Pollard RB, et al. Increased frequency of regulatory $\mathrm{T}$ cells accompanies increased immune activation in rectal mucosae of HIV-positive noncontrollers. $J$ Virol (2011) 85:11422-34. doi:10.1128/JVI.05608-11

135. Kinter A, McNally J, Riggin L, Jackson R, Roby G, Fauci AS. Suppression of HIV-specific T cell activity by lymph node CD25(+) regulatory T cells from HIV-infected individuals. Proc Natl Acad Sci U S A (2007) 104:3390-5. doi:10.1073/pnas.0611423104

136. Chomont N, El-Far M, Ancuta P, Trautmann L, Procopio FA, Yassine-Diab B, et al. HIV reservoir size and persistence are driven by T cell survival and homeostatic proliferation. Nat Med (2009) 15:893-900. doi:10.1038/nm.1972

137. Estes JD, Kityo C, Ssali F, Swainson L, Makamdop KN, Del Prete GQ, et al. Defining total-body AIDS-virus burden with implications for curative strategies. Nat Med (2017) 23(11):1271-6. doi:10.1038/nm.4411

138. Cubas RA, Mudd JC, Savoye A-L, Perreau M, van Grevenynghe J, Metcalf T, et al. Inadequate $\mathrm{T}$ follicular cell help impairs B cell immunity during HIV infection. Nat Med (2013) 19:494-9. doi:10.1038/nm.3109

139. Miles B, Miller SM, Folkvord JM, Kimball A, Chamanian M, Meditz AL, et al. Follicular regulatory T cells impair follicular T helper cells in HIV and SIV infection. Nat Commun (2015) 6:8608. doi:10.1038/ncomms9608 
140. Hong JJ, Amancha PK, Rogers K, Ansari AA, Villinger F. Spatial alterations between CD4(+) T follicular helper, B, and CD8(+) $\mathrm{T}$ cells during simian immunodeficiency virus infection: T/B cell homeostasis, activation, and potential mechanism for viral escape. J Immunol (2012) 188:3247-56. doi:10.4049/jimmunol.1103138

141. Lindqvist M, van Lunzen J, Soghoian DZ, Kuhl BD, Ranasinghe S, Kranias G, et al. Expansion of HIV-specific T follicular helper cells in chronic HIV infection. J Clin Invest (2012) 122:3271-80. doi:10.1172/ JCI64314

142. Petrovas C, Yamamoto T, Gerner MY, Boswell KL, Wloka K, Smith EC, et al. CD4 T follicular helper cell dynamics during SIV infection. J Clin Invest (2012) 122:3281-94. doi:10.1172/JCI63039

143. Brocca-Cofano E, Kuhrt D, Siewe B, Xu C, Haret-Richter GS, Craigo J, et al. Pathogenic correlates of the simian immunodeficiency virus (SIV)-associated B cell dysfunction. J Virol (2017) 91. doi:10.1128/jvi. 01051-17

144. De Milito A, Nilsson A, Titanji K, Thorstensson R, Reizenstein E, Narita M, et al. Mechanisms of hypergammaglobulinemia and impaired antigenspecific humoral immunity in HIV-1 infection. Blood (2004) 103:2180-6. doi:10.1182/blood-2003-07-2375

145. Preite S, Baumjohann D, Foglierini M, Basso C, Ronchi F, Fernandez Rodriguez BM, et al. Somatic mutations and affinity maturation are impaired by excessive numbers of $\mathrm{T}$ follicular helper cells and restored by Treg cells or memory T cells. Eur J Immunol (2015) 45:3010-21. doi:10.1002/ eji.201545920

146. Chowdhury A, Del Rio PME, Tharp GK, Trible RP, Amara RR, Chahroudi A, et al. Decreased T follicular regulatory cell/T follicular helper cell (TFH) in simian immunodeficiency virus-infected Rhesus macaques may contribute to accumulation of TFH in chronic infection. J Immunol (2015) 195:3237-47. doi:10.4049/jimmunol.1502269

147. Blackburn MJ, Zhong-Min M, Caccuri F, McKinnon K, Schifanella L, Guan Y, et al. Regulatory and helper follicular T cells and antibody avidity to simian immunodeficiency virus glycoprotein 120. J Immunol (2015) 195:3227-36. doi:10.4049/jimmunol.1402699

148. Miller SM, Miles B, Guo K, Folkvord J, Meditz AL, McCarter MD, et al. Follicular regulatory $\mathrm{T}$ cells are highly permissive to R5-tropic HIV-1. J Virol (2017) 91. doi:10.1128/JVI.00430-17

149. Aandahl EM, Michaëlsson J, Moretto WJ, Hecht FM, Nixon DF. Human CD4+ CD25+ regulatory T cells control T-cell responses to human immunodeficiency virus and cytomegalovirus antigens. J Virol (2004) 78:2454-9. doi:10.1128/JVI.78.5.2454-2459.2004

150. Carbonneil C, Donkova-Petrini V, Aouba A, Weiss L. Defective dendritic cell function in HIV-infected patients receiving effective highly active antiretroviral therapy: neutralization of IL-10 production and depletion of CD4+CD25+ T cells restore high levels of HIV-specific CD4+ T cell responses induced by dendritic cells generated in the presence of IFN- $\alpha$. J Immunol (2004) 172:7832-40. doi:10.4049/jimmunol.172.12.7832

151. Kinter AL, Hennessey M, Bell A, Kern S, Lin Y, Daucher M, et al. CD25+CD4+ regulatory $\mathrm{T}$ cells from the peripheral blood of asymptomatic $\mathrm{HIV}$-infected individuals regulate CD4+ and CD8+ HIV-specific T cell immune responses in vitro and are associated with favorable clinical markers of disease status. J Exp Med (2004) 200:331-43. doi:10.1084/jem.20032069

152. Weiss L, Donkova-Petrini V, Caccavelli L, Balbo M, Carbonneil C, Levy Y. Human immunodeficiency virus-driven expansion of CD4+CD25+ regulatory $\mathrm{T}$ cells, which suppress HIV-specific CD4 T-cell responses in HIVinfected patients. Blood (2004) 104:3249-56. doi:10.1182/blood-2004-01-0365

153. Kornfeld C, Ploquin MJ, Pandrea I, Faye A, Onanga R, Apetrei C, et al. Antiinflammatory profiles during primary SIV infection in African green monkeys are associated with protection against AIDS. J Clin Invest (2005) 115:1082-91. doi:10.1172/JCI23006C1

154. Cecchinato V, Tryniszewska E, Ma ZM, Vaccari M, Boasso A, Tsai W-P, et al. Immune activation driven by CTLA-4 blockade augments viral replication at mucosal sites in simian immunodeficiency virus infection. J Immunol (2008) 180:5439-47. doi:10.4049/jimmunol.180.8.5439

155. Whitney JB, Hill AL, Sanisetty S, Penaloza-MacMaster P, Liu J, Shetty M, et al. Rapid seeding of the viral reservoir prior to SIV viraemia in rhesus monkeys. Nature (2014) 512:74-7. doi:10.1038/nature13594

156. Kinter AL, Horak R, Sion M, Riggin L, McNally J, Lin Y, et al. CD25+ regulatory $\mathrm{T}$ cells isolated from HIV-infected individuals suppress the cytolytic and nonlytic antiviral activity of HIV-specific CD8+ T cells in vitro. AIDS Res Hum Retroviruses (2007) 23:438-50. doi:10.1089/aid.2006.0162

157. Elahi S, Dinges WL, Lejarcegui N, Laing KJ, Collier AC, Koelle DM, et al. Protective HIV-specific CD8+ T cells evade Treg cell suppression. Nat Med (2011) 17:989-95. doi:10.1038/nm.2422

158. Jiang Q, Zhang L, Wang R, Jeffrey J, Washburn ML, Brouwer D, et al. FoxP3 ${ }^{+} \mathrm{CD}^{+}$ regulatory $\mathrm{T}$ cells play an important role in acute HIV-1 infection in humanized $\mathrm{Rag}^{-/-} \gamma \mathrm{C}^{-/-}$mice in vivo. Blood (2008) 112:2858-68. doi:10.1182/ blood-2008-03-145946

159. Angin M, Kwon DS, Streeck H, Wen F, King M, Rezai A, et al. Preserved function of regulatory $\mathrm{T}$ cells in chronic HIV-1 infection despite decreased numbers in blood and tissue. J Infect Dis (2012) 205:1495-500. doi:10.1093/ infdis/jis 236

160. Moreno-Fernandez ME, Zapata W, Blackard JT, Franchini G, Chougnet CA. Human regulatory $\mathrm{T}$ cells are targets for human immunodeficiency virus (HIV) infection, and their susceptibility differs depending on the HIV type 1 strain. J Virol (2009) 83:12925-33. doi:10.1128/JVI.01352-09

161. Pion M, Jaramillo-Ruiz D, Martinez A, Munoz-Fernandez MA, CorreaRocha R. HIV infection of human regulatory T cells downregulates Foxp3 expression by increasing DNMT3b levels and DNA methylation in the FOXP3 gene. AIDS (2013) 27:2019-29. doi:10.1097/QAD.0b013e32836253fd

162. Angin M, Sharma S, King M, Murooka TT, Ghebremichael M, Mempel TR et al. HIV-1 infection impairs regulatory T-cell suppressive capacity on a per-cell basis. J Infect Dis (2014) 210:899-903. doi:10.1093/infdis/jiu188

163. Oswald-Richter K, Grill SM, Shariat N, Leelawong M, Sundrud MS, Haas DW, et al. HIV infection of naturally occurring and genetically reprogrammed human regulatory T-cells. PLoS Biol (2004) 2:e198. doi:10.1371/journal. pbio.0020198

164. Tran T-A, de Goër de Herve M-G, Hendel-Chavez H, Dembele B, Le Névot E, Abbed K, et al. Resting regulatory CD4 T cells: a site of HIV persistence in patients on long-term effective antiretroviral therapy. PLoS One (2008) 3:e3305. doi:10.1371/journal.pone.0003305

165. Jiao Y-M, Liu C-E, Luo L-J, Zhu W-J, Zhang T, Zhang L-G, et al. CD4+ CD25+CD127 regulatory cells play multiple roles in maintaining HIV-1 p24 production in patients on long-term treatment: HIV-1 p24-producing cells and suppression of anti-HIV immunity. Int J Infect Dis (2015) 37:42-9. doi:10.1016/j.ijid.2015.06.008

166. Dunay GA, Solomatina A, Kummer S, Hüfner A, Bialek JK, Eberhard JM, et al. Assessment of the HIV-1 reservoir in CD4+ regulatory T cells by a droplet digital PCR based approach. Virus Res (2017) 240:107-11. doi:10.1016/j. virusres.2017.07.008

167. Pandrea I, Gaufin T, Brenchley JM, Gautam R, Monjure C, Gautam A, et al. Cutting edge: experimentally induced immune activation in natural hosts of simian immunodeficiency virus induces significant increases in viral replication and CD4+ T cell depletion. J Immunol (2008) 181:6687-91. doi:10.4049/jimmunol.181.10.6687

168. He T, Brocca-Cofano E, Policicchio BB, Sivanandham R, Gautam R, Raehtz KD, et al. Cutting edge: $\mathrm{T}$ regulatory cell depletion reactivates latent simian immunodeficiency virus (SIV) in controller macaques while boosting SIV-specific T lymphocytes. J Immunol (2016) 197:4535-9. doi:10.4049/ jimmunol.1601539

169. Shirley M. Daclizumab: a review in relapsing multiple sclerosis. Drugs (2017) 77:447-58. doi:10.1007/s40265-017-0708-2

170. Milo R. The efficacy and safety of daclizumab and its potential role in the treatment of multiple sclerosis. Ther Adv Neurol Disord (2014) 7:7-21. doi:10.1177/1756285613504021

171. Waldmann TA, White JD, Carrasquillo JA, Reynolds JC, Paik CH, Gansow OA, et al. Radioimmunotherapy of interleukin-2R alpha-expressing adult T-cell leukemia with Yttrium-90-labeled anti-Tac. Blood (1995) 86:4063-75.

172. Waldmann TA. Daclizumab (anti-Tac, Zenapax) in the treatment of leukemia/ lymphoma. Oncogene (2007) 26:3699-703. doi:10.1038/sj.onc.1210368

173. Wang Z, Wei M, Zhang H, Chen H, Germana S, Huang CA, et al. Diphtheria-toxin based anti-human CCR4 immunotoxin for targeting human CCR4(+) cells in vivo. Mol Oncol (2015) 9:1458-70. doi:10.1016/j. molonc.2015.04.004

174. Wang Z, Pratts SG, Zhang H, Spencer PJ, Yu R, Tonsho M, et al. Treg depletion in non-human primates using a novel diphtheria toxin-based antihuman CCR4 immunotoxin. Mol Oncol (2016) 10:553-65. doi:10.1016/j. molonc.2015.11.008 
175. Ni X, Jorgensen JL, Goswami M, Challagundla P, Decker WK, Kim YH, et al. Reduction of regulatory $\mathrm{T}$ cells by Mogamulizumab, a defucosylated anti-CC chemokine receptor 4 antibody, in patients with aggressive/ refractory mycosis fungoides and Sezary syndrome. Clin Cancer Res (2015) 21:274-85. doi:10.1158/1078-0432.CCR-14-0830

176. Ogura M, Ishida T, Hatake K, Taniwaki M, Ando K, Tobinai K, et al. Multicenter phase II study of mogamulizumab (KW-0761), a defucosylated anti-cc chemokine receptor 4 antibody, in patients with relapsed peripheral T-cell lymphoma and cutaneous T-cell lymphoma. J Clin Oncol (2014) 32:1157-63. doi:10.1200/JCO.2013.52.0924

177. Walter S, Weinschenk T, Stenzl A, Zdrojowy R, Pluzanska A, Szczylik C, et al. Multipeptide immune response to cancer vaccine IMA901 after single-dose cyclophosphamide associates with longer patient survival. Nat Med (2012) 18:1254-61. doi:10.1038/nm.2883

178. Ghiringhelli F, Menard C, Puig PE, Ladoire S, Roux S, Martin F, et al. Metronomic cyclophosphamide regimen selectively depletes CD4+CD25+ regulatory $\mathrm{T}$ cells and restores $\mathrm{T}$ and $\mathrm{NK}$ effector functions in end stage cancer patients. Cancer Immunol Immunother (2007) 56:641-8. doi:10.1007/ s00262-006-0225-8

179. Wightman F, Solomon A, Kumar SS, Urriola N, Gallagher K, Hiener B, et al. Effect of ipilimumab on the HIV reservoir in an HIV-infected individual with metastatic melanoma. AIDS (2015) 29:504-6. doi:10.1097/QAD. 0000000000000562

180. Hryniewicz A, Boasso A, Edghill-Smith Y, Vaccari M, Fuchs D, Venzon D, et al. CTLA- 4 blockade decreases TGF- $\beta$, IDO, and viral RNA expression in tissues of SIVmac251-infected macaques. Blood (2006) 108:3834-42. doi:10.1182/blood-2006-04-010637

181. Boasso A, Vaccari M, Fuchs D, Hardy AW, Tsai W-P, Tryniszewska E, et al. Combined effect of antiretroviral therapy and blockade of IDO in SIVinfected Rhesus macaques. J Immunol (2009) 182:4313-20. doi:10.4049/ jimmunol.0803314

182. Vaccari M, Boasso A, Fenizia C, Fuchs D, Hryniewicz A, Morgan T, et al. Fatal pancreatitis in simian immunodeficiency virus SIVmac251infected macaques treated with $2^{\prime}, 3^{\prime}$-dideoxyinosine and stavudine following cytotoxic-T-lymphocyte-associated antigen 4 and indoleamine 2,3-dioxygenase blockade. J Virol (2012) 86:108-13. doi:10.1128/ JVI.05609-11

183. Queen C, Schneider WP, Selick HE, Payne PW, Landolfi NF, Duncan JF, et al. A humanized antibody that binds to the interleukin 2 receptor. Proc Natl Acad Sci U S A (1989) 86:10029-33. doi:10.1073/pnas.86.24.10029

184. Williams DP, Parker K, Bacha P, Bishai W, Borowski M, Genbauffe F, et al. Diphtheria toxin receptor binding domain substitution with interleukin-2: genetic construction and properties of a diphtheria toxin-related interleukin-2 fusion protein. Protein Eng (1987) 1:493-8. doi:10.1093protein/ 1.6 .493

185. Collier RJ. Diphtheria toxin: mode of action and structure. Bacteriol Rev (1975) 39:54-85.

186. Kaminetzky D, Hymes KB. Denileukin diftitox for the treatment of cutaneous T-cell lymphoma. Biologics (2008) 2:717-24. doi:10.2147/BTT.S3084

187. Atchison E, Eklund J, Martone B, Wang L, Gidron A, Macvicar G, et al. A pilot study of denileukin diftitox (DD) in combination with high-dose interleukin-2 (IL-2) for patients with metastatic renal cell carcinoma (RCC). J Immunother (2010) 33:716-22. doi:10.1097/CJI.0b013e3181e4752e

188. Foss FM, Sjak-Shie N, Goy A, Jacobsen E, Advani R, Smith MR, et al. A multicenter phase II trial to determine the safety and efficacy of combination therapy with denileukin diftitox and cyclophosphamide, doxorubicin, vincristine and prednisone in untreated peripheral T-cell lymphoma: the CONCEPT study. Leuk Lymphoma (2013) 54:1373-9. doi:10.3109/1042819 4.2012.742521

189. Telang S, Rasku MA, Clem AL, Carter K, Klarer AC, Badger WR, et al. Phase II trial of the regulatory T cell-depleting agent, denileukin diftitox, in patients with unresectable stage IV melanoma. BMC Cancer (2011) 11:515. doi:10.1186/1471-2407-11-515

190. Baur AS, Lutz MB, Schierer S, Beltrame L, Theiner G, Zinser E, et al. Denileukin diftitox (ONTAK) induces a tolerogenic phenotype in dendritic cells and stimulates survival of resting Treg. Blood (2013) 122:2185-94. doi:10.1182/blood-2012-09-456988

191. Waldmann TA, White JD, Goldman CK, Top L, Grant A, Bamford R, et al. The interleukin-2 receptor: a target for monoclonal antibody treatment of human T-cell lymphotrophic virus I-induced adult T-cell leukemia. Blood (1993) 82:1701-12.

192. O’Mahony D, Morris J, Carrasquillo J, Le N, Paik C, Whatley M, et al. Phase I/II study of Yttrium-90 labeled humanized anti-Tac (HAT) monoclonal antibody and calcium DTPA in CD25-expressing malignancies. J Nucl Med (2006) 47:98.

193. Vincenti F, Kirkman R, Light S, Bumgardner G, Pescovitz M, Halloran P, et al. Interleukin-2-receptor blockade with daclizumab to prevent acute rejection in renal transplantation. N Engl J Med (1998) 338:161-5. doi:10.1056/ NEJM199801153380304

194. Li G, Nunoya JI, Cheng L, Reszka-Blanco N, Tsao LC, Jeffrey J, et al. Regulatory T cells contribute to HIV-1 reservoir persistence in CD4 T cells through cAMP-dependent mechanisms in humanized mice in vivo. J Infect Dis (2017) 216(12):1579-91. doi:10.1093/infdis/jix547

195. Ma D, Xu C, Cillo AR, Policicchio B, Kristoff J, Haret-Richter G, et al. Simian immunodeficiency virus SIVsab infection of Rhesus macaques as a model of complete immunological suppression with persistent reservoirs of replication-competent virus: implications for cure research. J Virol (2015) 89:6155-60. doi:10.1128/JVI.00256-15

196. Pandrea I, Gaufin T, Gautam R, Kristoff J, Mandell D, Montefiori D, et al. Functional cure of SIVagm infection in rhesus macaques results in complete recovery of CD4+ $\mathrm{T}$ cells and is reverted by CD8+ cell depletion. PLoS Pathog (2011) 7:e1002170. doi:10.1371/journal.ppat.1002170

197. Peraino JS, Zhang H, Rajasekera PV, Wei M, Madsen JC, Sachs DH, et al. Diphtheria toxin-based bivalent human IL-2 fusion toxin with improved efficacy for targeting human CD25(+) cells. J Immunol Methods (2014) 405:57-66. doi:10.1016/j.jim.2014.01.008

198. Wang Z, Zheng Q, Zhang H, Bronson RT, Madsen JC, Sachs DH, et al. Ontak-like human IL-2 fusion toxin. J Immunol Methods (2017) 448:51-8. doi:10.1016/j.jim.2017.05.008

199. Ishida T, Ueda R. CCR4 as a novel molecular target for immunotherapy of cancer. Cancer Sci (2006) 97:1139-46. doi:10.1111/j.1349-7006.2006.00307.x

200. Nishikawa H, Sakaguchi S. Regulatory $\mathrm{T}$ cells in tumor immunity. Int J Cancer (2010) 127:759-67. doi:10.1002/ijc.25429

201. Iellem A, Mariani M, Lang R, Recalde H, Panina-Bordignon P, Sinigaglia F, et al. Unique chemotactic response profile and specific expression of chemokine receptors CCR4 and CCR8 by CD4(+)CD25(+) regulatory T cells. J Exp Med (2001) 194:847-53. doi:10.1084/jem.194.6.847

202. Agrawal L, Vanhorn-Ali Z, Alkhatib G. Multiple determinants are involved in HIV coreceptor use as demonstrated by CCR4/CCL22 interaction in peripheral blood mononuclear cells (PBMCs). J Leukoc Biol (2002) 72:1063-74. doi:10.1189/jlb.72.5.1063

203. Appelbaum FR, Sullivan KM, Buckner CD, Clift RA, Deeg HJ, Fefer A, et al. Treatment of malignant lymphoma in 100 patients with chemotherapy, total body irradiation, and marrow transplantation. J Clin Oncol (1987) 5:1340-7. doi:10.1200/JCO.1987.5.9.1340

204. McCune WJ, Golbus J, Zeldes W, Bohlke P, Dunne R, Fox DA. Clinical and immunologic effects of monthly administration of intravenous cyclophosphamide in severe systemic lupus erythematosus. N Engl J Med (1988) 318:1423-31. doi:10.1056/NEJM198806023182203

205. Gladstone DE, Prestrud AA, Pradhan A, Styler MJ, Topolsky DL, Crilley PA, et al. High-dose cyclophosphamide for severe systemic lupus erythematosus. Lupus (2002) 11:405-10. doi:10.1191/0961203302lu229oa

206. Petri M, Brodsky RA, Jones RJ, Gladstone D, Fillius M, Magder LS. High dose cyclophosphamide versus monthly intravenous cyclophosphamide for systemic lupus erythematosus. Arthritis Rheum (2010) 62:1487-93. doi:10.1002/art.27371

207. Glode LM, Barqawi A, Crighton F, Crawford ED, Kerbel R. Metronomic therapy with cyclophosphamide and dexamethasone for prostate carcinoma. Cancer (2003) 98:1643-8. doi:10.1002/cncr.11713

208. Lutsiak MEC, Semnani RT, De Pascalis R, Kashmiri SVS, Schlom J, Sabzevari H. Inhibition of $\mathrm{CD}^{+} 25^{+} \mathrm{T}$ regulatory cell function implicated in enhanced immune response by low-dose cyclophosphamide. Blood (2005) 105:2862-8. doi:10.1182/blood-2004-06-2410

209. Ikezawa Y, Nakazawa M, Tamura C, Takahashi K, Minami M, Ikezawa Z. Cyclophosphamide decreases the number, percentage and the function of CD25+ CD4+ regulatory $\mathrm{T}$ cells, which suppress induction of contact hypersensitivity. J Dermatol Sci (2005) 39:105-12. doi:10.1016/j.jdermsci. 2005.02.002 
210. Heylmann D, Bauer M, Becker H, van Gool S, Bacher N, Steinbrink K, et al. Human CD4+CD25+ regulatory $\mathrm{T}$ cells are sensitive to low dose cyclophosphamide: implications for the immune response. PLoS One (2013) 8:e83384. doi:10.1371/journal.pone.0083384

211. Zhao J, Cao Y, Lei Z, Yang Z, Zhang B, Huang B. Selective depletion of $\mathrm{CD}^{+} \mathrm{CD}^{2} 5^{+} \mathrm{Foxp}^{+}$regulatory $\mathrm{T}$ cells by low-dose cyclophosphamide is explained by reduced intracellular ATP levels. Cancer Res (2010) 70:4850-8. doi:10.1158/0008-5472.CAN-10-0283

212. Loyher PL, Rochefort J, Baudesson de Chanville C, Hamon P, Lescaille G, Bertolus C, et al. CCR2 influences T regulatory cell migration to tumors and serves as a biomarker of cyclophosphamide sensitivity. Cancer Res (2016) 76:6483-94. doi:10.1158/0008-5472.CAN-16-0984

213. Nakahara T, Uchi H, Lesokhin AM, Avogadri F, Rizzuto GA, HirschhornCymerman D, et al. Cyclophosphamide enhances immunity by modulating the balance of dendritic cell subsets in lymphoid organs. Blood (2010) 115:4384-92. doi:10.1182/blood-2009-11-251231

214. Camisaschi C, Filipazzi P, Tazzari M, Casati C, Beretta V, Pilla L, et al. Effects of cyclophosphamide and IL-2 on regulatory CD4(+) T cell frequency and function in melanoma patients vaccinated with HLA-class I peptides: impact on the antigen-specific T cell response. Cancer Immunol Immunother (2013) 62:897-908. doi:10.1007/s00262-013-1397-7

215. Alonso CM, Lozada CJ. Effects of IV cyclophosphamide on HIV viral replication in a patient with systemic lupus erythematosus. Clin Exp Rheumatol (2000) 18:510-2.

216. Bartlett JA, Miralles GD, Sevin AD, Silberman M, Pruitt SK, Ottinger J, et al. Addition of cyclophosphamide to antiretroviral therapy does not diminish the cellular reservoir in HIV-infected persons. AIDS Res Hum Retroviruses (2002) 18:535-43. doi:10.1089/088922202753747888

217. McGary CS, Deleage C, Harper J, Micci L, Ribeiro SP, Paganini S, et al. CTLA-4+PD-1- memory CD4+ T cells critically contribute to viral persistence in antiretroviral therapy-suppressed, SIV-infected Rhesus macaques. Immunity (2017) 47:776-88.e5. doi:10.1016/j.immuni.2017.09.018

218. Kaufmann DE, Kavanagh DG, Pereyra F, Zaunders JJ, Mackey EW, Miura T, et al. Upregulation of CTLA-4 by HIV-specific CD4+ T cells correlates with disease progression and defines a reversible immune dysfunction. Nat Immunol (2007) 8:1246-54. doi:10.1038/ni1515

219. Elrefaei M, Burke CM, Baker CAR, Jones NG, Bousheri S, Bangsberg DR, et al. HIV-specific TGF- $\beta$-positive CD4(+) T cells do not express regulatory surface markers and are regulated by CTLA-4. AIDS Res Hum Retroviruses (2010) 26:329-37. doi:10.1089/aid.2009.0149

220. Asano T, Meguri Y, Yoshioka T, Kishi Y, Iwamoto M, Nakamura M, et al. PD-1 modulates regulatory T-cell homeostasis during low-dose interleukin-2 therapy. Blood (2017) 129:2186-97. doi:10.1182/blood-2016-09-741629

221. Wang W, Lau R, Yu D, Zhu W, Korman A, Weber J. PD1 blockade reverses the suppression of melanoma antigen-specific CTL by CD4(+)CD25(Hi) regulatory T cells. Int Immunol (2009) 21:1065-77. doi:10.1093/intimm/ dxp072

222. Streeck H, Brumme ZL, Anastario M, Cohen KW, Jolin JS, Meier A, et al. Antigen load and viral sequence diversification determine the functional profile of HIV-1-specific CD8+ T cells. PLoS Med (2008) 5:e100. doi:10.1371/ journal.pmed.0050100

223. Blackburn SD, Shin H, Haining WN, Zou T, Workman CJ, Polley A, et al. Coregulation of CD8+ $\mathrm{T}$ cell exhaustion by multiple inhibitory receptors during chronic viral infection. Nat Immunol (2009) 10:29-37. doi:10.1038/ ni. 1679

224. Catakovic K, Klieser E, Neureiter D, Geisberger R. T cell exhaustion: from pathophysiological basics to tumor immunotherapy. Cell Commun Signal (2017) 15:1. doi:10.1186/s12964-016-0160-Z

225. Boasso A, Herbeuval JP, Hardy AW, Anderson SA, Dolan MJ, Fuchs D, et al. HIV inhibits CD4+ T-cell proliferation by inducing indoleamine 2,3-dioxygenase in plasmacytoid dendritic cells. Blood (2007) 109:3351-9. doi:10.1182/blood-2006-07-034785

Conflict of Interest Statement: The authors declare that the research was conducted in the absence of any commercial or financial relationships that could be construed as a potential conflict of interest.

The reviewer MP and handling Editor declared their shared affiliation.

Copyright (c) 2018 Kleinman, Sivanandham, Pandrea, Chougnet and Apetrei. This is an open-access article distributed under the terms of the Creative Commons Attribution License (CC BY). The use, distribution or reproduction in other forums is permitted, provided the original author(s) and the copyright owner are credited and that the original publication in this journal is cited, in accordance with accepted academic practice. No use, distribution or reproduction is permitted which does not comply with these terms. 